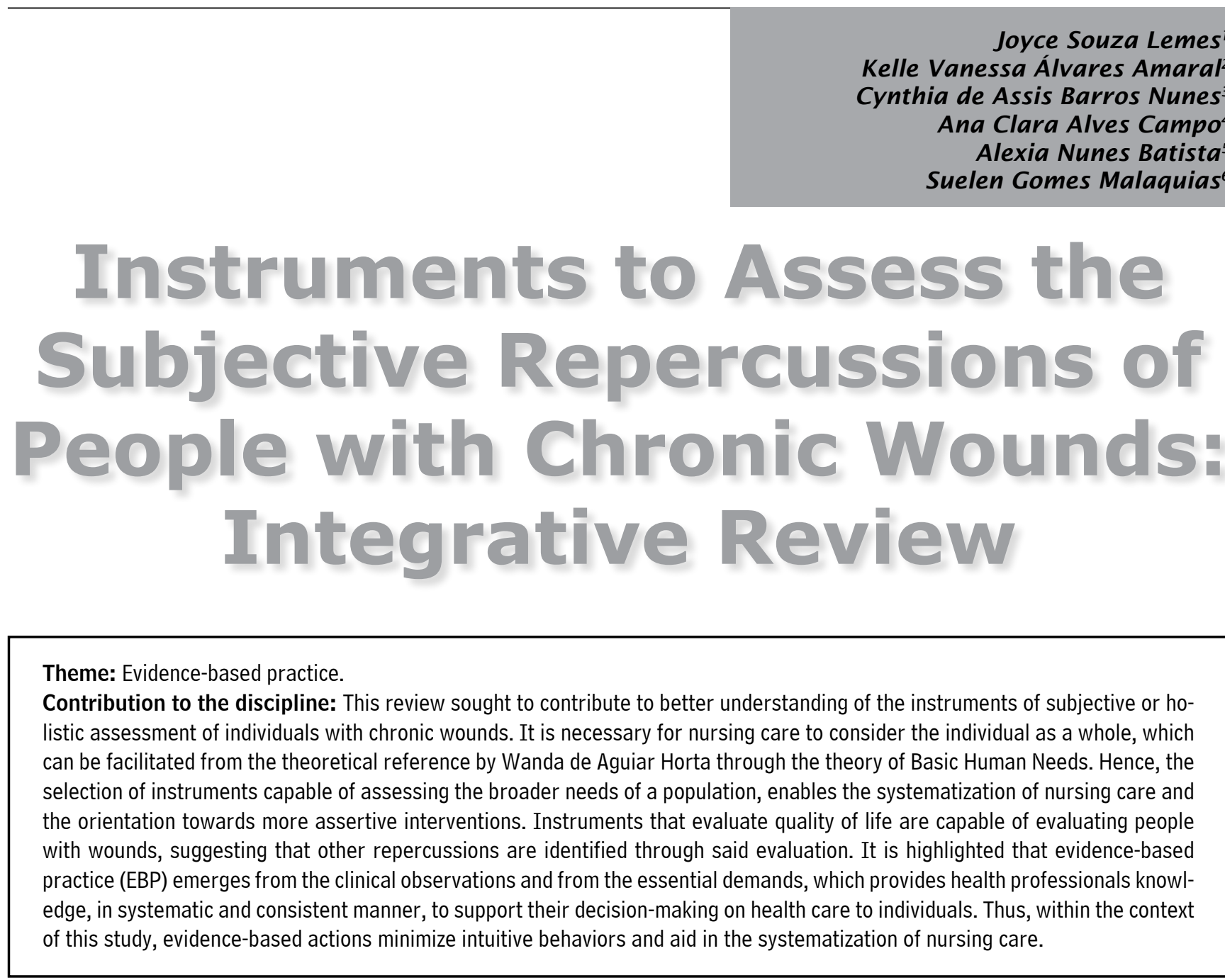

\title{
ABSTRACT
}

Objective: To analyze the instruments described in the literature for extended assessment in people with chronic wound. Materials and methods: Study of integrative review of the literature. The search was conducted on databases including PUBMED, Web of Science, SciELO, CINAHL, Science Direct (Elsevier), Scopus, and Biblioteca Virtual da Saúde (BVS). Results: The search found 19060 articles; after relevance tests, 41 were left. The instrument most used in the studies of this review was the Short Form 36 Health Survery (SF-36), which is a tool to assess quality of life (QOL). Conclusion: A diversity of instruments was identified for extended assessment of people with wounds, with those investigating QOL being the most frequent. The repercussions are, mostly, contained in the QOL assessment instru-

\section{DOI: 10.5294/aqui.2019.19.1.8}

To reference this article / Para citar este artículo / Para citar este artigo Lemes JS, Amaral KVA, Nunes CAB, Campos ACA, Batista AN, Malaquias SG. Instruments to Assess the Subjective Repercussions of People with Chronic Wounds: Integrative Review. Aquichan 2019; 19(1): e1918. DOI: 10.5294/aqui.2019.19.1.8

1 orcid.org/0000-0002-7401-2608. Faculdade de Enfermagem, Universidade Federal de Goiás, Brazil. joyce@enf.grad.ufg.br

2 orcid.org/0000-0002-9758-4270. Faculdade de Enfermagem, Universidade Federal de Goiás, Brazil. kelle.amaral@ebserh.gov.br

3 orcid.org/0000-0001-8322-8737. Faculdade de Enfermagem, Universidade Federal de Goiás, Brazil. chyntia@posgrad.ufg.br

4 orcid.org/0000-0002-1683-7249. Faculdade de Enfermagem, Universidade Federal de Goiás, Brazil. anaclara@enf.grad.ufg.br

5 orcid.org/0000-0002-0031-4400. Faculdade de Enfermagem, Universidade Federal de Goiás, Brazil. alexianb@enf.grad.ufg.br

$6 \bowtie$ orcid.org/0000-0001-8530-9100. Faculdade de Enfermagem, Universidade Federal de Goiás, Brazil. suelen.g.malaquias@ufg.br
Received: 28/07/2018

Sent to peer reviewers: 22/08/2018

Accepted by peers: $28 / 10 / 2018$

Approved submission: 29/11/2018 
ments, but superficially and/or not explicitly, as in the SF-36, the means most-frequently identified in the studies of this review. These findings suggest the likelihood of differentiated implications of these instruments according to the etiology of the lesions, psychosocial and psychospiritual needs of the individual, as well as the context to which they are destined, like teaching, clinical practice, or research.

KEYWORDS (SOURCE: DeCS)

Quality of life; wounds and injuries; leg ulcer; evaluation; evaluation of research programs and tools.

\section{Instrumentos para evaluar las repercusiones subjetivas de personas con heridas crónicas: revisión integrativa}

\section{RESUMEN}

Objetivo: analizar los instrumentos descritos en la literatura para evaluación ampliada en personas con herida crónica. Material y métodos: estudio de revisión integrativa de la literatura. La investigación se realizó en las bases de datos PUBMED, Web of Science, SciElo, CINAHL, Science Direct (Elsevier), Scopus y Biblioteca Virtual de la Salud (BVS). Resultados: se encontraron 19060 artículos; después de las pruebas de relevancia, quedaron 41. El instrumento más utilizado en los estudios de esta revisión fue el Short Form 36 Health Survery (SF-36), que es una herramienta de evaluación de la calidad de vida (CV). Conclusión: se identificaronó diversidad de instrumentos para evaluación ampliada de personas con heridas, siendo los de investigación de la CV los más frecuentes. Las repercusiones están, en su mayoría, contenidas en los instrumentos de evaluación de la CV, pero de forma superficial y/o poco explícita, como en el SF-36, medio más frecuentemente identificado en los estudios de esta revisión. Estos hallazgos sugieren la posibilidad de implicaciones diferenciadas de esos instrumentos según la etiología de las lesiones, necesidades psicosociales y psicoespirituales del individuo, así como el contexto a que se destinan, tales quales enseñanza, práctica clínica o investigación.

\section{PALABRAS CLAVE (FUENTE: DECS)}

Calidad de vida; heridas y lesiones; úlcera de la pierna; evaluación; evaluación de programas e instrumentos de investigación. 


\section{Instrumentos para avaliação das repercussões subjetivas de pessoas com feridas crônicas: revisão integrativa}

\section{RESUMO}

Objetivo: analisar os instrumentos descritos na literatura para avaliação ampliada em pessoas com ferida crônica. Material e métodos: estudo de revisão integrativa da literatura. A busca foi feita nas bases de dados PUBMED, Web of Science, SciElo, CINAHL, Science Direct (Elsevier), Scopus, e Biblioteca Virtual da Saúde (BVS). Resultados: foram encontrados 19060 artigos; após os testes de relevância, restaram quatro. 0 instrumento mais utilizado nos estudos dessa revisão foi o SF-36, que é uma ferramenta de avaliação da qualidade de vida (QV). Conclusão: identificou-se diversidade de instrumentos para avaliação ampliada de pessoas com feridas, sendo os de investigação da QV os mais frequentes. As repercussões estão, em sua maioria, contidas nos instrumentos de avalição de QV, porém de forma superficial e/ou pouco explícita, como no Short Form 36 Health Survery (SF-36), meio mais frequentemente identificado nos estudos dessa revisão. Esses achados sugerem a possibilidade de implicações diferenciadas desses instrumentos conforme a etiologia das lesões, necessidades psicossociais e psicoespirituais do indivíduo, bem como o contexto a que se destinam, tais como ensino, prática clínica ou pesquisa.

PALAVRAS-CHAVE (FONTE: DeCS)

Qualidade de vida; ferimentos e lesões; úlcera da perna; avaliação; avaliação de programas e instrumentos de pesquisa. 


\section{Introduction}

The occurrence of chronic wound, to the demands and limitations caused by the ulcer, triggers several representations to individuals. In this sense, it is possible that the following situations are observed: Chronic pain syndrome, change in body image, reduced work capacity, and altered family and social dynamics. They can lead individuals to a condition of social isolation, which impacts upon their quality of life $(\mathrm{QOL})(1,2)$.

To adequately care for these individuals, technical-scientific knowledge is necessary that considers aspects that go beyond the topical care of lesions. It is necessary to address the impacts of wounds on the daily lives of individuals, respecting the feelings, sensations, and biopsychosocial needs that must be addressed (3).

To be resolute in the context of clinical practice, interventions in the aforementioned situations must be systematized and based on scientific evidence, so that cases are duly followed up. In this sense, strategies exist to aid professionals to minimize the bias of subjectivity associated with this type of evaluation.

It is known that to make a holistic approach in people with chronic comorbidities, it is necessary to consider the aspects mentioned. Nevertheless, identifying those conditions may not be a simple task, given that these are aspects involving personal interpretations or impressions. This makes the evaluations made by the professionals superficial, detailed, or very subjective.

An important tool to guide said assessment is the use of Patient Report Outcome Measures (PROM), which are instruments that permit knowing and measuring patients' opinions about their health and which, when applied during different moments of treatment, enable monitoring possible changes. These instruments serve as an aid because they estimate the evaluation in measurable manner and favor follow-up without the evaluator's personal impressions (4).

Currently, several instruments are available for said purpose in diverse populations, even in people with wounds. However, it is observed that each study chooses a method, based on its priorities, and indicates somewhat inconclusive results regarding the use of the method chosen. Knowing the instruments that evaluate beyond the conditions of healing can contribute to the integral care of the individual, as well as influence upon decisions of care, treatment and/or interventions, along with the formulation of health programs and institutional policies (5).

Thus, this research is justified by the need to identify which of these instruments are or are not validated and to evidence their particularities. The initiative can favor the actions of professionals caring for people with those characteristics, with the purpose of optimizing the evaluation of psychophysiological repercussions.

By identifying the most effective instruments, it is possible to plan more assertive interventions in clinical practice and conduct experimental research, as well as aid in the professional formation of nurses and other professionals caring for said patients.

\section{Objective}

To analyze instruments of subjective evaluation of people with chronic wound described in the literature.

\section{Materials and methods}

This was a study of integrative review of the literature, conducted from August 2016 to July 2017. For the purpose of reporting this study, the work followed the recommendations of the Preferred Reporting Items for Systematic Reviews and MetaAnalyses (PRISMA). This is a checklist with 27 items, seeking to help authors to direct, more consistently and objectively, the presentation of systematic reviews and meta-analyses (6).

To elaborate the research question, the PVO strategy was used, where $(P)$ is the person with chronic wound, $(V)$ are the evaluation instruments, and $(0)$ the outcomes the individual presents (6). The guiding question of this study was: What instruments are used for a subjective evaluation in people with chronic wounds?

The research included articles written between February 2006 and February 2017; in Portuguese, English, and Spanish; articles dealing with extended evaluation in people with chronic wounds (pressure lesions and/or leg ulcer, patients with complications in the feet due to diabetes mellitus, psoriasis), and also articles that use instruments for this evaluation. Dissertations, theses, book chapters, editorials, reviews, comments, abstracts, systematic and integrative review articles, and duplicate articles were excluded. 
On 16 February 2017, a search was conducted in the following databases: National Library of Medicine (Medicine PUBMED), Web of Science, Electronic Library Online (SciELO), Cumulative Index of Nursing and Allied Health Literature (CINAHL), Science Direct (Elsevier), Science Direct (Scopus), and Biblioteca Virtual em Saúde (BVS). The following search strategy was used: "quality of life" OR "fatigue" OR "pain" OR "anxiety" OR "depression" AND "wounds and injures" OR "leg ulcer" OR "varicose ulcer" OR "pressure ulcer" OR "diabetic foot" AND "evaluation" OR "evaluation of research programs and tools".

The 19060 articles identified in the search were saved, on the same day via E-mail, to control and apply relevance tests (RT) elaborated according to the inclusion criteria, which were established from the research question (7). The study considered articles in English, Portuguese, and Spanish, published between 2006 and 2017, and which addressed leg ulcer or holistic subjective assessment of the individual. First, the RT was applied to the titles of the articles identified, configuring RT 1 , and, thereafter, the abstracts, representing the RT 2. Thus, duplicates, theses, dissertations, monographs, book chapters, editorials, opinion articles, and literature reviews were also excluded.

A form was drawn up to extract data from each article. Thus, extraction, organization, and summarization of information continued through the analysis of authenticity, methodological quality, importance of information, and representativeness, as well as the judgment of the study with regard to the degree of evidence $(7,8)$. To verify the degree of evidence of each article selected, the study used the Joanna Briggs reviewer's manual, elaborated as a comprehensive guide to conduct systematic reviews, by categorizing the studies from their methodological designs (8).

\section{Results}

From the search in all the databases, 19060 articles were obtained; by applying the relevance test 1,18726 were excluded because of language, temporal cut prior to 2006, and not addressing repercussions among people with chronic wounds. Thereafter the relevance test 2 was applied, which excluded 293 articles because they did not contain instruments of extended assessment, and being duplicates and literature review articles, theses, dissertations, opinion articles, course completion works, and editorials. Thus, 41 articles were included to read in full and extract data (Figure 1).
Figure 1. Flowchart of the study inclusion process

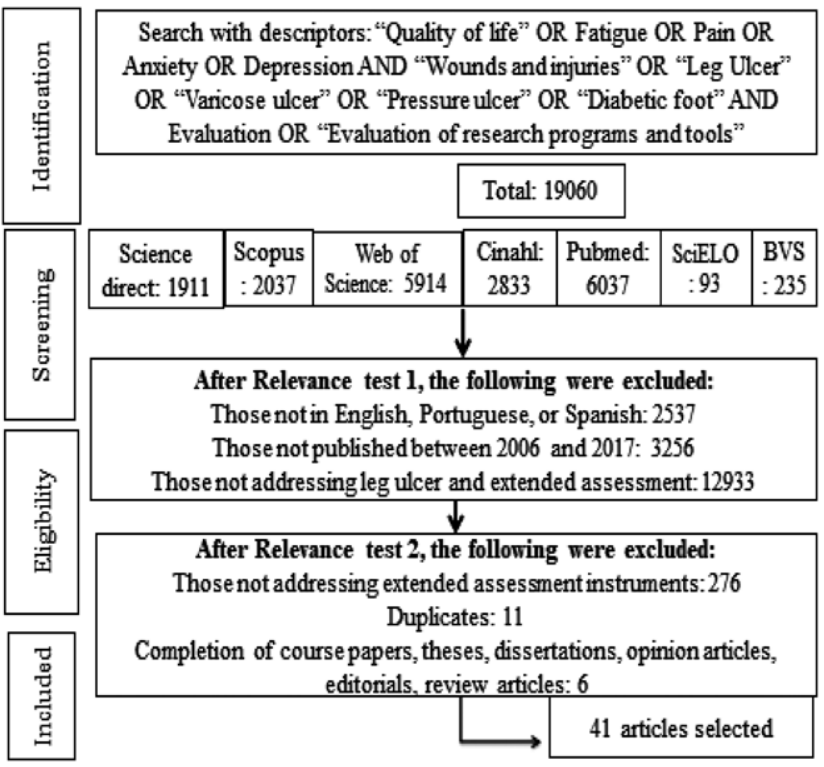

Source: Own elaboration.

Table 1 evidences the characterization of the 41 studies selected, according to methodological design, population, objective, conclusion, and level of evidence, according to recommendations by the Joanna Briggs Institute (8).

A higher number of publications was identified after 2014, indicating a growing demand for greater understanding on aspects concerning the extended assessment of people with chronic wounds.

With regards to types of studies, 26 (63.4\%) were cross-sectional, $10(24.4 \%)$ validation, translation, and adaptation of instruments, two (4.9\%) were pilot studies, two (4.9\%) control cases, and one $(2.4 \%)$ cohort study. There was prevalence of research conducted in American countries (51.2\%), of which $76.2 \%$ were Brazilian, followed by European studies (43.9\%). With respect to the authors' formation area, 20 (48.8\%) were from Medicine, 11 (26.8\%) from Nursing, 6 (14.6\%) from Physiotherapy, and 4 (9.8\%) from Nutrition.

In relation to the characteristics of the populations studied, 31 studies $(75.6 \%)$ had prevalence of female gender; in $63.4 \%$ of the studies, age ranged between 60 and 70 years. The comorbidities found were diabetes (39\%), vascular disease (26.8\%), diabetes and 
Table 1. Characterization of the studies according to type, population, objective, conclusion, and level of evidence. Goiania, 2017.

\begin{tabular}{|c|c|c|c|c|c|c|c|}
\hline \multirow{2}{*}{$\mathbf{N}^{\circ}$} & \multirow{2}{*}{$\begin{array}{l}\text { Type of } \\
\text { study }\end{array}$} & \multirow{2}{*}{$\begin{array}{l}\text { Location } \\
\text { of study }\end{array}$} & \multicolumn{2}{|c|}{ Population } & \multirow{2}{*}{ Objective of the study } & \multirow{2}{*}{ Principal findings } & \multirow{2}{*}{$\begin{array}{l}\text { Level of } \\
\text { evidence }\end{array}$} \\
\hline & & & Age & Sex & & & \\
\hline $\mathrm{El}(9)$ & $\begin{array}{l}\text { Exploratory, } \\
\text { descriptive, } \\
\text { cross- } \\
\text { sectional }\end{array}$ & Brazil & $\begin{array}{l}<6041 \% \\
60-7058 \% \\
>701 \%\end{array}$ & $\begin{array}{l}\text { More } \\
\text { than } 50 \\
\% \mathrm{~F}\end{array}$ & $\begin{array}{l}\text { Observe and compare feelings of powerlessness } \\
\text { in people with venous ulcer and in people with foot } \\
\text { ulcer due to complications of Diabetes Mellitus } \\
\text { (DM) using the Powerlessness Assessment Tool } \\
\text { (PAT) scale. }\end{array}$ & $\begin{array}{l}\text { The results indicated that patients with venous disease } \\
\text { e foot ulcer due to complications of DM had very strong } \\
\text { feelings of powerlessness for living with this. Said } \\
\text { feelings are significantly stronger in patients with foot } \\
\text { ulcer due to complications of DM (P: 0.002). }\end{array}$ & $4 b$ \\
\hline E2 (10) & $\begin{array}{l}\text { Cross- } \\
\text { sectional, } \\
\text { descriptive } \\
\text { and analytic } \\
\text { study }\end{array}$ & $\begin{array}{l}\text { The } \\
\text { United } \\
\text { Kingdom }\end{array}$ & $\begin{array}{l}\text { Mean of } 65 \\
\text { years }\end{array}$ & $54 \% \mathrm{~F}$ & $\begin{array}{c}\text { Test the Pressure Ulcer QOL (PU-QOL) among } \\
\text { people with Pressure lesion (PL). }\end{array}$ & $\begin{array}{l}\text { The PU-QOL instrument provides a standardized } \\
\text { method to assess QOL (QOL) specific of the pressure } \\
\text { ulcer. }\end{array}$ & $4 b$ \\
\hline E3 (11) & $\begin{array}{l}\text { Cross- } \\
\text { sectional, } \\
\text { descriptive } \\
\text { and analytic } \\
\text { study }\end{array}$ & Germany & $\begin{array}{l}\text { Mean of } \\
67.8 \text { years }\end{array}$ & $55 \% \mathrm{~F}$ & $\begin{array}{l}\text { Assess the level of pain of patients related to leg } \\
\text { ulcer and determine the impact of said pain on the } \\
\text { QOL of said patients, using the EQ 5D instrument. }\end{array}$ & $\begin{array}{l}\text { In } 46 \% \text { of the participants with pain, it was identified } \\
\text { that high levels of pain correlated with worse health } \\
\text { status. Greater reduction of QOL was noted related to } \\
\text { pain for women (R20.56, men; R20.08, women). }\end{array}$ & $4 b$ \\
\hline E4 (12) & $\begin{array}{l}\text { Cross- } \\
\text { sectional } \\
\text { comparative } \\
\text { study }\end{array}$ & Greece & $\begin{array}{l}\text { Mean } 48.2 \\
\text { years }\end{array}$ & $50 \% \mathrm{~F}$ & $\begin{array}{c}\text { Compare QOL, anxiety and depression, self-esteem } \\
\text { and feeling of loneliness in patients with psoriasis } \\
\text { and leg ulcer (LU). }\end{array}$ & $\begin{array}{l}\text { Both groups present worse conditions of the items } \\
\text { evaluated. People with psoriasis present greater } \\
\text { loneliness, social isolation, and anxiety }(\mathrm{p}<0.001) \\
\text { than people with LU. Self-esteem had no significant } \\
\text { difference between the groups. }\end{array}$ & $4 b$ \\
\hline E5 (13) & $\begin{array}{l}\text { Observation- } \\
\text { al, cross- } \\
\text { sectional, } \\
\text { analytic, } \\
\text { multicenter } \\
\text { study }\end{array}$ & Spain & $\begin{array}{c}\text { Mean of } \\
72.06 \text { years }\end{array}$ & $55 \% \mathrm{M}$ & $\begin{array}{l}\text { Determine QOL in patients with venous ulcer and } \\
\text { the relation severity of the ulcer loss of QOL, as } \\
\text { well as identify the aspects of QOL most negatively } \\
\text { affected by the venous ulcer. }\end{array}$ & $\begin{array}{l}\text { Relationship exists between severity of the ulcer and } \\
\text { lower QOL ( } r: 0.546 ; p \leq 0.001 \text { ). Presence of non-via- } \\
\text { ble tissue, exudate and infection determine worse QOL. } \\
\text { New studies are necessary to confirm said findings. }\end{array}$ & $4 b$ \\
\hline E6 (14) & $\begin{array}{l}\text { Cross- } \\
\text { sectional, } \\
\text { random } \\
\text { multicenter } \\
\text { study }\end{array}$ & Canada & $\begin{array}{c}\text { Mean of } 65 \\
\text { years }\end{array}$ & $55 \% \mathrm{~F}$ & $\begin{array}{l}\text { Observe the association between sociodemo- } \\
\text { graphic and clinical factors and QOL in patients } \\
\text { with chronic leg ulcer. }\end{array}$ & $\begin{array}{l}\text { Higher levels of pain }(p<0.01 ; C I=1.3-4.7) \text {, lower } \\
\text { age }(p<0.01 ; C I=1.1-1.5) \text {, higher time of ulcer dura- } \\
\text { tion }(p<0.01 ; C I=1.7-5.0) \text {, limitation in mobility }(p= \\
0.02 ; C I=1.2-3.2) \text { were associated to worse QOL. }\end{array}$ & lc \\
\hline E7 (15) & $\begin{array}{l}\text { Prospective } \\
\text { non-random- } \\
\text { ized cohort } \\
\text { study }\end{array}$ & $\begin{array}{l}\text { The } \\
\text { United } \\
\text { Kingdom }\end{array}$ & $\begin{array}{l}\text { Mean of } \\
69.7 \text { years }\end{array}$ & $76 \% \mathrm{M}$ & $\begin{array}{l}\text { Evaluate factors associated to the healing process } \\
\text { and impact of the limb loss on the QOL of patients } \\
\text { with foot ulcer due to complications of DM. }\end{array}$ & $\begin{array}{l}\text { In all the domains of the Diabetic Foot Scale (DFS), } \\
\text { QOL was improved over the cohort of our patients ( }<< \\
0.0001) \text {, independent of their outcome (healing or am- } \\
\text { putation). Significant improvement was also observed } \\
\text { in self-care after follow up. }\end{array}$ & $3 c$ \\
\hline E8 (16) & $\begin{array}{l}\text { Cross- } \\
\text { sectional, } \\
\text { descriptive, } \\
\text { analytic } \\
\text { study }\end{array}$ & Brazil & $\begin{array}{c}31.7 \% \\
<60 \\
65 \% 61-70 \\
33 \%>70\end{array}$ & $73 \% \mathrm{~F}$ & $\begin{array}{l}\text { Identify feelings of powerlessness among people } \\
\text { with venous ulcer, from the (PAT) scale. }\end{array}$ & $\begin{array}{l}\text { High PAT scores were identified, revealing strong (32 } \\
\% \text { ) or very strong ( } 52 \% \text { ) feelings of powerlessness, } \\
\text { which can provoke negative effects on QOL. }\end{array}$ & $4 b$ \\
\hline E9 (17) & $\begin{array}{l}\text { Compara- } \\
\text { tive, cross- } \\
\text { sectional } \\
\text { study }\end{array}$ & Brazil & $\begin{array}{l}\text { Mean of } 65 \\
\text { years }\end{array}$ & $80 \% \mathrm{~F}$ & $\begin{array}{l}\text { Evaluate QOL and self-esteem in patients with foot } \\
\text { ulcer due to complications of DM. }\end{array}$ & $\begin{array}{l}\text { Patients with ulcer on diabetic foot present lower QOL } \\
\text { regarding physical aspects ( } p=0.043) \text {, functional } \\
\text { capacity ( } p=0.003) \text {, social aspects ( } p=0.022) \text {, } \\
\text { emotional aspects }(p=001) \text {. There was no statistical } \\
\text { difference of self-esteem among groups of diabetic } \\
\text { patients without ulcer. }\end{array}$ & $4 b$ \\
\hline
\end{tabular}




\begin{tabular}{|c|c|c|c|c|c|c|c|}
\hline \multirow{2}{*}{$\mathrm{N}^{\circ}$} & \multirow{2}{*}{$\begin{array}{l}\text { Type of } \\
\text { study }\end{array}$} & \multirow{2}{*}{$\begin{array}{l}\text { Location } \\
\text { of study }\end{array}$} & \multicolumn{2}{|c|}{ Population } & \multirow{2}{*}{ Objective of the study } & \multirow{2}{*}{ Principal findings } & \multirow{2}{*}{$\begin{array}{l}\text { Level of } \\
\text { evidence }\end{array}$} \\
\hline & & & Age & Sex & & & \\
\hline $\begin{array}{l}\text { E10 } \\
(18)\end{array}$ & $\begin{array}{l}\text { Cross- } \\
\text { sectional } \\
\text { study }\end{array}$ & India & $\begin{array}{c}\text { Mean of } 62 \\
\text { years }\end{array}$ & $58.5 \% \mathrm{~F}$ & $\begin{array}{l}\text { Evaluate the impact of foot ulcer on QOL of diabetic } \\
\text { patients, using the RAND } 36 \text { scale and the DFS } \\
\text { scale. }\end{array}$ & $\begin{array}{l}\text { Diabetic patients with and without foot ulcer had } \\
\text { impaired QOL (score }<50 \text { points). The group of patients } \\
\text { with foot ulcer due to complication of DM presented } \\
\text { compromised QOL in all six domains of DSF - Short } \\
\text { Form. Patients with foot ulcer due to complication of } \\
\text { DM had worse QOL when compared to diabetic patients } \\
\text { without ulcer. }\end{array}$ & $4 b$ \\
\hline $\begin{array}{l}\text { Ell } \\
(19)\end{array}$ & $\begin{array}{l}\text { Quantitative, } \\
\text { descriptive } \\
\text { and cross- } \\
\text { sectional } \\
\text { research }\end{array}$ & Brazil & $\begin{array}{l}38 \text { to } 59 \\
\text { years }\end{array}$ & $63.3 \% \mathrm{~F}$ & $\begin{array}{l}\text { Analyze the impact of venous ulcers on the QOL of } \\
\text { people attended in primary health care. }\end{array}$ & $\begin{array}{l}\text { Compromise of QOL was identified, the most affected } \\
\text { dimensions were emotional state and aesthetics, } \\
\text { especially in individuals with lesion for more than a } \\
\text { year. Association was observed between current time } \\
\text { of lesion and emotional state (p: } 0.008) \text {, in which indi- } \\
\text { viduals with lesion for more than one year had higher } \\
\text { measurements (64.5). }\end{array}$ & $4 b$ \\
\hline $\begin{array}{l}\text { E12 } \\
(20)\end{array}$ & $\begin{array}{l}\text { Observa- } \\
\text { tional cross- } \\
\text { sectional } \\
\text { study }\end{array}$ & Portugal & $\begin{array}{l}\text { Mean } 71.9 \\
\text { years }\end{array}$ & $63.3 \% \mathrm{~F}$ & $\begin{array}{c}\text { Evaluate the impact of chronic leg ulcers on QOL of } \\
\text { patients in Portugal using the Nottingham Health } \\
\text { Profile (NHP) scale, and verify changes after } 12 \\
\text { weeks of treatment. }\end{array}$ & $\begin{array}{l}\text { Patients had high scores in all NPH domains. After } 12 \\
\text { weeks, an increase was noted in all the dimensions of } \\
\text { NPH and a statistically significant improvement, in pain } \\
\text { (p: } 0.003) \text { and in the EuroQOL score (p: } 0.027) \text {. }\end{array}$ & $4 b$ \\
\hline $\begin{array}{l}\text { E13 } \\
(21)\end{array}$ & Control case & $\begin{array}{l}\text { The } \\
\text { United } \\
\text { States }\end{array}$ & $\begin{array}{c}\text { Mean of } 57 \\
\text { years }\end{array}$ & $80 \% \mathrm{~F}$ & $\begin{array}{l}\text { Compare the QOL of patients with chronic neuropa- } \\
\text { thy (Charcot) with and without ulcerations on the } \\
\text { feet due to complications of DM. }\end{array}$ & $\begin{array}{l}\text { The study did not evidence significant difference in } \\
\text { QOL among patients with chronic neuropathy with and } \\
\text { without foot ulcer, due to complications of DM, except } \\
\text { for the subscale bodily pain, which had lower scores in } \\
\text { patients who did not have ulcer (p: } 0.04 \text { ). }\end{array}$ & $3 d$ \\
\hline $\begin{array}{l}\text { E14 } \\
(22)\end{array}$ & $\begin{array}{l}\text { Cross- } \\
\text { sectional } \\
\text { study }\end{array}$ & $\begin{array}{l}\text { Czech } \\
\text { Republic }\end{array}$ & $\begin{array}{c}\text { Mean of } 64 \\
\text { years }\end{array}$ & $72 \% \mathrm{M}$ & $\begin{array}{l}\text { Evaluate the influence of pain on QOL of patients } \\
\text { with foot ulcer due to complication of DM. }\end{array}$ & $\begin{array}{l}\text { The ulcer affects significantly the QOL of the patient. } \\
\text { Patients who had pain with greater frequency evidence } \\
\text { lower QOL. A statistically negative correlation was } \\
\text { found among the intensity of pain and } Q 0 \mathrm{~L} \text { in the } \\
\text { following domains: Physical health }(r=0.592 ; p< \\
\begin{array}{r}0.001) \text {, daily activities }(r=0.456 ; p<0.001) \text {, emotions } \\
(r=0.503 ; p<0.001) \text {, and treatment }(r=0.434, p \\
<0.001) \text {. }\end{array}\end{array}$ & $4 b$ \\
\hline $\begin{array}{l}\text { El5 } \\
(23)\end{array}$ & $\begin{array}{l}\text { Instrument } \\
\text { validation } \\
\text { study }\end{array}$ & Colombia & $\begin{array}{l}\text { Mean of } \\
78.6 \text { years }\end{array}$ & $63 \% \mathrm{~F}$ & $\begin{array}{l}\text { Validate the Spanish version of the Charing Cross } \\
\text { Venous Ulcer Questionnaire (CCVUQ-e). }\end{array}$ & $\begin{array}{l}\text { The CCVUQ-e has good internal consistency (Cron- } \\
\text { bach's alpha } \geq 0.80 \text { ). The correlation between the } \\
\text { CCVUQ-e and the PUSH-e, at the beginning of the } \\
\text { search, was r: } 0.49 \text { (p: } \leq 0.001 \text { ), and, after six weeks } \\
\text { it was r: } 0.64 \text { (p: } 0.006) \text {. The instruments demonstrated } \\
\text { adequate sensitivity to change ( } \mathrm{p}: \leq 0.001 \text { ). Hence, } \\
\text { the preliminary results show that the CCVUQ-e has } \\
\text { satisfactory psychometric properties. }\end{array}$ & $4 b$ \\
\hline $\begin{array}{l}\text { El6 } \\
(24)\end{array}$ & $\begin{array}{l}\text { Cross- } \\
\text { sectional } \\
\text { study }\end{array}$ & Brazil & $\begin{array}{c}\text { Mean of } 60 \\
\text { years }\end{array}$ & $74.5 \% \mathrm{~F}$ & $\begin{array}{l}\text { Compare the QOL of patients with chronic venous } \\
\text { disease with and without ulcer and identify the } \\
\text { most affected aspects. }\end{array}$ & $\begin{array}{l}\text { The QOL of patients with and without venous ulcer was } \\
\text { different in the eight domains and in both dimensions } \\
\text { of SF-36 ( } p<0.05) \text {. The most affected aspects were: } \\
\text { Physical aspect }(p<0.001) \text {, functional capacity ( } p< \\
0.001) \text {, social aspects }(p<0.001) \text {, and physical health } \\
(p<0.001) \text {. People with venous ulcer had worse QOL } \\
\text { when compared to people without that lesion. }\end{array}$ & $4 b$ \\
\hline $\begin{array}{l}\text { E17 } \\
(25)\end{array}$ & $\begin{array}{l}\text { A cross- } \\
\text { sectional } \\
\text { probabilistic } \\
\text { study }\end{array}$ & Brazil & $\begin{array}{l}\text { Mean of } \\
52.8 \text { years }\end{array}$ & $62 \% \mathrm{~F}$ & $\begin{array}{l}\text { Evaluate QOL and analyze the association between } \\
\text { personal characteristics and health in QOL of } \\
\text { patients with chronic leg ulcers. }\end{array}$ & $\begin{array}{l}\text { The sampling had better } \mathrm{QOL} \text { (median }=21.6 ; \mathrm{SD}= \\
\text { 3.4). The domain of health and functioning had the } \\
\text { lowest scores (median }=19.7 ; \mathrm{SD}=3.7 \text { ). Age }(\mathrm{p}= \\
\text { 0.0165), number of children }(\mathrm{p}=0.0083 \text { ), and religious } \\
\text { practice ( } \mathrm{p}=0.0394 \text { ) had significant positive effect } \\
\text { on QOL. }\end{array}$ & $4 b$ \\
\hline
\end{tabular}




\begin{tabular}{|c|c|c|c|c|c|c|c|}
\hline \multirow{2}{*}{$\mathrm{N}^{\circ}$} & \multirow{2}{*}{$\begin{array}{l}\text { Type of } \\
\text { study }\end{array}$} & \multirow{2}{*}{$\begin{array}{l}\text { Location } \\
\text { of study }\end{array}$} & \multicolumn{2}{|c|}{ Population } & \multirow{2}{*}{ Objective of the study } & \multirow{2}{*}{ Principal findings } & \multirow{2}{*}{$\begin{array}{l}\text { Level of } \\
\text { evidence }\end{array}$} \\
\hline & & & Age & Sex & & & \\
\hline $\begin{array}{l}\text { E18 } \\
(26)\end{array}$ & Control case & Greece & $\begin{array}{l}\text { Mean of } \\
62.29 \text { years }\end{array}$ & $51 \% \mathrm{M}$ & $\begin{array}{l}\text { Evaluate QOL, anxiety, and depression, self-esteem } \\
\text { and loneliness in patients with leg ulcer. }\end{array}$ & $\begin{array}{c}\text { Patients of female gender had a higher score of anxiety } \\
(p=0.027) \text { and social isolation }(p=0.048) \text { and worse } \\
\text { QOL }(p=0.018) \text { than patients of male gender. A seri- } \\
\text { ous compromise of QOL was observed, and reflected } \\
\text { significant psychosocial impact in patients with leg } \\
\text { ulcers }(p<0.05) \text {. }\end{array}$ & $3 d$ \\
\hline $\begin{array}{l}\text { E19 } \\
(27)\end{array}$ & $\begin{array}{l}\text { Descriptive } \\
\text { cross- } \\
\text { sectional } \\
\text { study }\end{array}$ & $\begin{array}{l}\text { The } \\
\text { United } \\
\text { States }\end{array}$ & $\begin{array}{l}\text { Mean of } \\
56.9 \text { years }\end{array}$ & $80 \% \mathrm{M}$ & $\begin{array}{l}\text { Compare QOL in patients with foot ulcer due to } \\
\text { complications of DM with and without infection. }\end{array}$ & $\begin{array}{l}\text { Scores of the physical aspects }(p<0.001) \text { and mental } \\
(p=0.025) \text { of SF- } 36 \text { were significantly reduced in } \\
\text { patients with infection indicated a negative effect on } \\
\text { general health, besides a reduction in the function of } \\
\text { the lower extremities }(p<0.001) \text {. }\end{array}$ & $4 b$ \\
\hline $\begin{array}{l}\text { E20 } \\
(28)\end{array}$ & $\begin{array}{l}\text { Validation } \\
\text { longitudinal } \\
\text { study }\end{array}$ & Germany & $\begin{array}{l}\text { Mean of } \\
65.3 \text { years }\end{array}$ & $54,5 \% \mathrm{M}$ & $\begin{array}{l}\text { Develop a questionnaire to evaluate } \mathrm{QOL} \text { in people } \\
\text { with chronic leg ulcers. }\end{array}$ & $\begin{array}{l}\text { The Wound-QOL has good internal consistency (Cron- } \\
\text { bach's alpha } 0.71 \text { to } 0.91 \text { ), convergent validity ( } r=0.48 \\
\text { to } 0.69 \text { ) and responsiveness ( } r=0.18 \text { to } 0.52) \text {. The } \\
\text { Wound-QOL has satisfactory psychometric properties } \\
\text { to assess QOL in people with leg ulcer in Germany. }\end{array}$ & $4 b$ \\
\hline $\begin{array}{l}\text { E21 } \\
(29)\end{array}$ & $\begin{array}{l}\text { Multicenter, } \\
\text { prospective, } \\
\text { descriptive, } \\
\text { analytic } \\
\text { study. }\end{array}$ & Brazil & $\begin{array}{l}\text { Between } \\
60 \text { and } 70 \\
\text { years }\end{array}$ & $\begin{array}{l}\text { Major- } \\
\text { ity F }\end{array}$ & $\begin{array}{l}\text { Evaluate self-esteem and bodily image of patients } \\
\text { with venous ulcer (VU). }\end{array}$ & $\begin{array}{l}\text { Low scores for bodily image }(7.43) \text {, bodily care }(5.71) \\
\text { and body touch ( } 12.3 \text { ) in patients with VU indicate } \\
\text { negative feelings regarding the body ( } p<0.05) \text {. In } \\
\text { addition, the low score }(22.66) \text { for the Rosenberg Self- } \\
\text { esteem (RSE) scale also indicates low self-esteem in } \\
\text { these patients }(p<0.05) \text {. }\end{array}$ & \\
\hline $\begin{array}{l}\text { E22 } \\
(30)\end{array}$ & $\begin{array}{l}\text { Cross- } \\
\text { sectional, } \\
\text { translation } \\
\text { and cultural } \\
\text { adaptation } \\
\text { study }\end{array}$ & Brazil & $\begin{array}{l}\text { Mean of } \\
56.2 \text { years }\end{array}$ & $100 \% \mathrm{~F}$ & $\begin{array}{l}\text { Translate and adapt the Charing Cross Venous } \\
\text { Ulcer Questionnaire for a Brazilian population. }\end{array}$ & $\begin{array}{l}\text { In the process of translation and adaptation, some } \\
\text { terms needed to be changed to facilitate their compre- } \\
\text { hension. The Charing Cross Venous Ulcer Questionnaire } \\
\text { was translated and adapted for use in a Brazilian } \\
\text { population. }\end{array}$ & $4 b$ \\
\hline $\begin{array}{l}\text { E23 } \\
(31)\end{array}$ & $\begin{array}{l}\text { Cross- } \\
\text { sectional, } \\
\text { translation } \\
\text { and cultural } \\
\text { adaptation } \\
\text { study }\end{array}$ & Brazil & $\begin{array}{l}\text { Mean of } \\
67.3 \text { years }\end{array}$ & $68 \% \mathrm{~F}$ & $\begin{array}{l}\text { Translate the Venous Leg Ulcer QOL Questionnaire } \\
\text { (VLU-QOL) into Brazilian Portuguese, culturally } \\
\text { adapt, and validate the VLU-QOL-Br questionnaire } \\
\text { for the Brazilian population. }\end{array}$ & $\begin{array}{l}\text { The instrument has high internal consistency (Cron- } \\
\text { bach's alpha: } 0.94 \text { ), good reproducibility (interclass } \\
\text { correlation coefficient: } 0.78 ; p<0.01 \text { ), the confirmatory } \\
\text { analysis maintained the same domains of the original } \\
\text { version of the instrument. The instrument has satisfac- } \\
\text { tory psychometric properties, which permits its use in } \\
\text { Brazil. It is recommended to evaluate its performance } \\
\text { in other regions and in different samples of individuals. }\end{array}$ & $4 b$ \\
\hline $\begin{array}{l}\text { E24 } \\
(32)\end{array}$ & $\begin{array}{l}\text { Cross- } \\
\text { sectional } \\
\text { instrument } \\
\text { validation }\end{array}$ & Brazil & $\begin{array}{l}\text { Mean of } \\
63.2 \text { years }\end{array}$ & $80 \% \mathrm{~F}$ & $\begin{array}{l}\text { Validate the Charing Cross Venous Ulcer Question- } \\
\text { naire for the Brazilian population. }\end{array}$ & $\begin{array}{l}\text { The instrument has good internal consistency (Cron- } \\
\text { bach's alpha: } 0.92 \text { ), high correlation in the evaluation of } \\
\text { inter-observer reproducibility and its stability, presents } \\
\text { inter-class correlation coefficients above } 0.80 \text { for } \\
\text { all domains. Furthermore, the instrument presented } \\
\text { reasonable correlations with the SF-36 domains. The } \\
\text { CCVUQ-Brazil is validated in Portuguese. }\end{array}$ & $4 b$ \\
\hline $\begin{array}{l}\text { E25 } \\
(33)\end{array}$ & $\begin{array}{l}\text { Multicenter, } \\
\text { randomized } \\
\text { instrument } \\
\text { validation } \\
\text { study }\end{array}$ & $\begin{array}{l}\text { The } \\
\text { United } \\
\text { Kingdom }\end{array}$ & $\begin{array}{l}\text { Mean of } \\
68.6 \text { years }\end{array}$ & $50.07 \mathrm{M}$ & $\begin{array}{l}\text { Validate the VEINES-QOL to evaluate QOL in people } \\
\text { with venous ulcer. }\end{array}$ & $\begin{array}{c}\text { The instrument has good internal consistency } \\
\text { (Cronbach's alpha: } 0.88 \text { ), reproducibility (interclass } \\
\text { correlation coefficient: } 0.80 \text { ), adequate correlation } \\
\text { with the components of the SF-12, and moderate } \\
\text { responsiveness. }\end{array}$ & lc \\
\hline $\begin{array}{l}\text { E26 } \\
(34)\end{array}$ & $\begin{array}{l}\text { Cross- } \\
\text { sectional } \\
\text { study }\end{array}$ & Brazil & $\begin{array}{l}\text { Mean of } 60 \\
\text { years }\end{array}$ & $53.6 \% \mathrm{~F}$ & $\begin{array}{c}\text { Evaluate a QOL in people with foot ulcer due to } \\
\text { complications of DM and its association with age } \\
\text { and gender. }\end{array}$ & $\begin{array}{l}\text { Participants presented domains of } \mathrm{QOL} \text { that tend to } \\
\text { have a worse health status, however, there was no } \\
\text { significant difference in the results between groups } \\
\text { regarding age and gender. }\end{array}$ & $4 b$ \\
\hline
\end{tabular}




\begin{tabular}{|c|c|c|c|c|c|c|c|}
\hline \multirow{2}{*}{$\mathrm{N}^{\circ}$} & \multirow{2}{*}{$\begin{array}{l}\text { Type of } \\
\text { study }\end{array}$} & \multirow{2}{*}{$\begin{array}{l}\text { Location } \\
\text { of study }\end{array}$} & \multicolumn{2}{|c|}{ Population } & \multirow{2}{*}{ Objective of the study } & \multirow{2}{*}{ Principal findings } & \multirow{2}{*}{$\begin{array}{l}\text { Level of } \\
\text { evidence }\end{array}$} \\
\hline & & & Age & Sex & & & \\
\hline $\begin{array}{l}\text { E27 } \\
(35)\end{array}$ & $\begin{array}{l}\text { Translation } \\
\text { and cultural } \\
\text { adaptation } \\
\text { study }\end{array}$ & Uruguay & $\begin{array}{l}\text { Mean of } \\
63.4 \text { years }\end{array}$ & $52 \% \mathrm{~F}$ & $\begin{array}{l}\text { Translate and adapt the Charing Cross Venous } \\
\text { Ulcer Questionnaire (CCVUQ) for Uruguay. }\end{array}$ & $\begin{array}{l}\text { The translation and adaptation of the version of CCVUQ } \\
\text { was easy to understand and apply, showing adequate } \\
\text { psychometric properties. }\end{array}$ & $4 b$ \\
\hline $\begin{array}{l}\text { E28 } \\
(36)\end{array}$ & $\begin{array}{l}\text { Obser- } \\
\text { vational } \\
\text { longitudinal } \\
\text { study }\end{array}$ & Germany & $\begin{array}{c}\text { Mean of } 62 \\
\text { years }\end{array}$ & $60 \% \mathrm{~F}$ & $\begin{array}{c}\text { Validate the Freiburg Life Quality Assessment } \\
\text { instrument to evaluate QOL in people with venous } \\
\text { ulcer. }\end{array}$ & $\begin{array}{l}\text { The instrument presented good internal consistency } \\
\text { (Cronbach's alpha: } \geq 0.85 \text { ), reliability, convergent } \\
\text { validity with the EuroQOL questionnaire of QOL (EQ-5D) } \\
\text { and sensitivity to change ( } r: 0.59-0.61 \text { ). }\end{array}$ & \\
\hline $\begin{array}{l}\text { E29 } \\
(37)\end{array}$ & $\begin{array}{l}\text { Cross- } \\
\text { sectional } \\
\text { analytic } \\
\text { study }\end{array}$ & Brazil & $\begin{array}{l}\text { Mean of } 55 \\
\text { years }\end{array}$ & $60 \% \mathrm{~F}$ & $\begin{array}{l}\text { Evaluate QOL and depression in elderly patients } \\
\text { with PL. }\end{array}$ & $\begin{array}{l}\text { Patients with LU had significantly low QOL scores, } \\
\text { when compared to the control group, in all domains } \\
\text { of the Short Form-36 (SF-36), with lower scores in the } \\
\text { domains physical function and emotional function ( } P \\
<0.0001) \text {. Seventy }(80.9 \square) \text { patients had depression } \\
\qquad(P=0.002) \text {. }\end{array}$ & $4 b$ \\
\hline $\begin{array}{l}\text { E30 } \\
(38)\end{array}$ & $\begin{array}{l}\text { Cross- } \\
\text { sectional } \\
\text { pilot study }\end{array}$ & $\begin{array}{l}\text { The } \\
\text { United } \\
\text { Kingdom }\end{array}$ & $\begin{array}{l}\text { Mean of } 70 \\
\text { years }\end{array}$ & $58 \% \mathrm{~F}$ & $\begin{array}{l}\text { Determine the impact of PL in (QOL) in people } \\
\text { with PL. }\end{array}$ & $\begin{array}{l}\text { PL impacts QOL negatively, independent of concomitant } \\
\text { comorbidities (diabetes, arthritis, CVA, cancer, ortho- } \\
\text { pedic, respiratory, neurological. In spite of borderline } \\
\text { significance ( } \mathrm{p}=0.06 \text { ), the pain perceived is higher } \\
\text { among people with LP. }\end{array}$ & $4 b$ \\
\hline $\begin{array}{l}\text { E31 } \\
(39)\end{array}$ & $\begin{array}{l}\text { Cross- } \\
\text { sectional } \\
\text { multicenter } \\
\text { study }\end{array}$ & Italy & $\begin{array}{l}\text { Mean of } 60 \\
\text { years }\end{array}$ & $61 \% \mathrm{~F}$ & $\begin{array}{l}\text { Access pain and QOL in patients with chronic leg } \\
\text { ulcer. }\end{array}$ & $\begin{array}{l}\text { Leg ulcers are painful and result in low QOL that is } \\
\text { directly related to the time of duration of the lesion } \\
\text { and its area. }\end{array}$ & $4 b$ \\
\hline $\begin{array}{l}\text { E32 } \\
(40)\end{array}$ & $\begin{array}{l}\text { Cross- } \\
\text { sectional } \\
\text { analytic }\end{array}$ & Turkey & $\begin{array}{l}\text { Between } \\
30 \text { and } 51 \\
\text { years }\end{array}$ & $65 \% \mathrm{M}$ & $\begin{array}{c}\text { Determine the correlation between depression and } \\
\text { level of social support perceived of people with foot } \\
\text { ulcers due to complications of DM. }\end{array}$ & $\begin{array}{l}\text { Depression and social support perceived correlate with } \\
\text { foot ulcers due to complications of DM }(p<0.01) \text {. }\end{array}$ & $4 b$ \\
\hline $\begin{array}{l}\text { E33 } \\
(41)\end{array}$ & $\begin{array}{l}\text { Translation } \\
\text { and adapta- } \\
\text { tion of the } \\
\text { instrument }\end{array}$ & Poland & $\begin{array}{l}\text { Mean of } \\
62.5 \text { years }\end{array}$ & $70 \% \mathrm{~F}$ & $\begin{array}{l}\text { Translate into Polish the Diabetic Foot Ulcer Scale } \\
\text { (DFS). }\end{array}$ & $\begin{array}{l}\text { The translated instrument can be used in Polish } \\
\text { patients. }\end{array}$ & $4 b$ \\
\hline $\begin{array}{l}\text { E34 } \\
(42)\end{array}$ & $\begin{array}{l}\text { Cross- } \\
\text { sectional } \\
\text { pilot study }\end{array}$ & Poland & $\begin{array}{l}\text { Mean of } 56 \\
\text { years }\end{array}$ & $75 \% \mathrm{~F}$ & $\begin{array}{c}\text { Compare QOL of people with vascular ulcers and } \\
\text { those with chronic venous insufficiency (CVI), } \\
\text { without ulcer. }\end{array}$ & $\begin{array}{l}\text { Significant differences were observed }(p<0.05) \text { on the } \\
\text { QOL of people with vascular ulcers and people with CVI } \\
\text { without chronic ulcer. }\end{array}$ & $4 b$ \\
\hline $\begin{array}{l}\text { E35 } \\
(43)\end{array}$ & $\begin{array}{l}\text { Methodolog- } \\
\text { ical study to } \\
\text { adapt and } \\
\text { validate the } \\
\text { instrument }\end{array}$ & Brazil & $\begin{array}{l}\text { Mean of } \\
55.7 \text { years }\end{array}$ & $54 \% \mathrm{~F}$ & $\begin{array}{l}\text { Adapt into Brazilian Portuguese and test reliability } \\
\text { and validity of the Brazilian version of the Neuropa- } \\
\text { thy - and Foot Ulcer - Specific QOL Instrument } \\
\text { - (NeuroQOL) to people with diabetic neuropathy } \\
\text { with foot ulcers. }\end{array}$ & $\begin{array}{l}\text { The findings evidence psychometric properties that con- } \\
\text { firm validity and reliability to NeuroQOL, with cultural } \\
\text { adaptation being necessary in other regions of Brazil. } \\
\text { Statistically significant correlations ( }<<0.01 \text { ) were } \\
\text { verified in domains of pain and mental component, loss } \\
\text { of sensitivity and physical component, anguish and } \\
\text { physical component, activities of daily life and physical } \\
\text { component. }\end{array}$ & $4 b$ \\
\hline $\begin{array}{l}\text { E36 } \\
(44)\end{array}$ & $\begin{array}{l}\text { Analytic, } \\
\text { cross-sec- } \\
\text { tional, con- } \\
\text { trolled, and } \\
\text { comparative } \\
\quad \text { study }\end{array}$ & Brazil & $\begin{array}{l}\text { Mean of } 55 \\
\text { years }\end{array}$ & $62 \% \mathrm{~F}$ & $\begin{array}{l}\text { Evaluate the QOL of people with DM with foot ulcer } \\
\text { in relation to people with DM without ulcer. }\end{array}$ & $\begin{array}{l}\text { In patients from the control group, the mean score of } \\
\text { the SF- } 36 \text { was } 69.38 \pm 21.90 \text { and from the study group, } \\
30.34 \pm 14.45(P<0.001) \text {. The mean scores in all SF- } \\
36 \text { domains of the study group were lower in relation } \\
\text { to the control group ( } P<0.001) \text {; thus, demonstrating } \\
\text { that diabetic patients with foot ulcer present changes in } \\
\text { QOL, which impacts multi-dimensionally. }\end{array}$ & $4 b$ \\
\hline $\begin{array}{l}\text { E37 } \\
(45)\end{array}$ & $\begin{array}{l}\text { Cross- } \\
\text { sectional } \\
\text { study }\end{array}$ & $\begin{array}{l}\text { The } \\
\text { United } \\
\text { Kingdom }\end{array}$ & $\begin{array}{c}\text { Mean of } 62 \\
\text { years }\end{array}$ & $60 \% \mathrm{M}$ & $\begin{array}{l}\text { Evaluate anxiety and depression of people with } \\
\text { Charcot foot due to complication of DM, compared } \\
\text { with diabetic individuals without foot complications. }\end{array}$ & $\begin{array}{l}\text { Patients with Charcot foot had high levels of mental } \\
\text { problems when compared to patients without ulcer. } \\
\text { Anxiety and depression had high scores, } 6.4 \pm 4 \text { and } \\
6.3 \pm 3.6 \text {, respectively. The risk of anxiety was not } \\
\text { significant, but the risk of depression was significant } \\
\qquad(p<0.05) \text {. }\end{array}$ & $4 b$ \\
\hline
\end{tabular}




\begin{tabular}{|c|c|c|c|c|c|c|c|}
\hline \multirow{2}{*}{$\mathrm{N}^{\circ}$} & \multirow{2}{*}{$\begin{array}{l}\text { Type of } \\
\text { study }\end{array}$} & \multirow{2}{*}{$\begin{array}{l}\text { Location } \\
\text { of study }\end{array}$} & \multicolumn{2}{|c|}{ Population } & \multirow{2}{*}{ Objective of the study } & \multirow{2}{*}{ Principal findings } & \multirow{2}{*}{$\begin{array}{l}\text { Level of } \\
\text { evidence }\end{array}$} \\
\hline & & & Age & Sex & & & \\
\hline $\begin{array}{l}\text { E38 } \\
(46)\end{array}$ & $\begin{array}{l}\text { Cross- } \\
\text { sectional } \\
\text { study }\end{array}$ & Brazil & $\begin{array}{l}\text { Mean of } 61 \\
\text { years }\end{array}$ & $59 \% \mathrm{~F}$ & $\begin{array}{l}\text { Evaluate level and intensity of depression of } \\
\text { patients with chronic wounds (venous ulcer, pres- } \\
\text { sure lesion, foot ulcer due to DM) from the Beck } \\
\text { inventory. }\end{array}$ & $\begin{array}{l}\text { Among patients with venous ulcer, } 7(28 \%) \text { had slight } \\
\text { to moderate depression and } 3(12 \%) \text { had moderate } \\
\text { to serious depression. Sixteen ( } 53.3 \%) \text { patients with } \\
\text { pressure ulcers manifested slight to moderate depres- } \\
\text { sion, and } 5(16.7 \%) \text {, moderate to serious depression; } \\
10(55.6 \%) \text { diabetic patients with foot ulcer had slight } \\
\text { to moderate depression, and } 4(22.20 \%) \text { without } \\
\text { depression or minimum depression. }\end{array}$ & $4 b$ \\
\hline $\begin{array}{l}\text { E39 } \\
(47)\end{array}$ & $\begin{array}{l}\text { Exploratory, } \\
\text { descriptive, } \\
\text { and cross- } \\
\text { sectional } \\
\text { study }\end{array}$ & Brazil & $\begin{array}{l}\text { Between } \\
60 \text { and } 69 \\
\text { years }\end{array}$ & $60 \% \mathrm{~F}$ & $\begin{array}{l}\text { Evaluate the intensity of depression and depressive } \\
\text { symptoms in diabetic patients with foot ulcers. }\end{array}$ & $\begin{array}{l}\text { Diabetic patients with foot ulcers had varying degrees } \\
\text { of depressive symptoms, with prevalence of "moder- } \\
\text { ate" level }(64 \%) \text { and symptoms: Self-depreciation, sad- } \\
\text { ness, and distortion of the bodily image. The statistical } \\
\text { difference between the levels "Minimum or none" and } \\
\text { "Moderate", with relation to number of depressive } \\
\text { symptoms, was significant }(p<0.001) \text {. }\end{array}$ & $4 b$ \\
\hline $\begin{array}{l}E 40 \\
(48)\end{array}$ & $\begin{array}{l}\text { Cross- } \\
\text { sectional } \\
\text { prospective } \\
\text { study }\end{array}$ & $\begin{array}{l}\text { The } \\
\text { United } \\
\text { States }\end{array}$ & $\begin{array}{l}\text { Mean of } \\
64.1 \text { years }\end{array}$ & $52 \% M$ & $\begin{array}{l}\text { It is determined that depression is associated to } \\
\text { increased incidence of foot ulcers of patients with } \\
\text { type } 2 \text { diabetes. }\end{array}$ & $\begin{array}{c}\text { Compared to patients without depression, patients with } \\
\text { higher depression have greater risk of having foot ulcer } \\
\text { due to complications of DM (CI }=1.24-3.25) \text {. There } \\
\text { was no statistically significant association within minor } \\
\text { depression. }\end{array}$ & $4 b$ \\
\hline E4l(49) & $\begin{array}{l}\text { Cross- } \\
\text { sectional } \\
\text { study }\end{array}$ & Norway & $\begin{array}{l}20 \text { years or } \\
\text { more }\end{array}$ & $60 \% \mathrm{~F}$ & $\begin{array}{l}\text { Compare levels of anxiety and depression, psy- } \\
\text { chological wellbeing and health perception among } \\
\text { people with diabetes, with or without history of } \\
\text { foot ulcer, and people from the community without } \\
\text { diabetes. }\end{array}$ & $\begin{array}{l}\text { Anxiety, depression, and perceived health had interac- } \\
\text { tion with age and presence of DM }(p=0.002) \text {. }\end{array}$ & $4 b$ \\
\hline
\end{tabular}

Source: Own elaboration.

hypertension (19.7\%), heart disease $(7.3 \%)$, orthopedic trauma ( $4.8 \%)$, neurological disorders (2.4\%), and cancer (2.4\%). The 11 studies that evaluated schooling of the participants identified complete primary education in seven $(63.6 \%)$, and four (36.4\%) with more than half the population being illiterate.

In terms of the etiology of the lesion, there was significant relevance of the studies of people with leg ulcers (LU) $(92.7 \%)$, followed by pressure lesion (7.3\%). Studies with LU identified those that evaluated different populations, of which $16(42.2 \%)$ addressed people with foot ulcers due to complications of diabetes mellitus (DM), $16(42 . \%)$ venous ulcer, two $(5.2 \%)$ arterial ulcer, one $(2.6 \%)$ neuropathic ulcer, one $(2.6 \%)$ compared populations with venous ulcer and ulcer due to complication of DM, one (2.6\%) compared people with ulcers due to psoriasis and leg ulcer, and one $(2.6 \%)$ compared populations with and without foot ulcers due to complications of DM.

Table 2 describes the assessment instruments used in the investigations. Of these, $15(36.5 \%)$ studies opted for using more than one instrument to evaluate the human repercussions investigated, or even evaluated more than one repercussion in the same study.

The most notable repercussion in the studies was QOL, identified in each in $35(85.3 \%)$ studies, followed by "pain" in five (12.2\%), self-esteem in five (12.2\%), depression in five (12.2 \%), anxiety and depression, together, in four $(9.7 \%)$, feeling of powerlessness in two (4.8\%), loneliness in two $(4.8 \%)$, perceived social support in one (2.4\%), and general health in one (2.4\%) study.

Considering the studies ( $\mathrm{n}=35,85.3 \%$ ) that evaluated QOL, concomitantly, three studies $(8.5 \%$ ) evaluated bio-physiological dimensions, sought correlations with QOL. Of these, one (33.3\%) evaluated the healing conditions through the Pressure Ulcer Scale Healing (PUSH); one (33.3\%), mental state through the Mental State Mini Exam; and one (33.3\%), the functional capacity of the ankle through the Foot Ankle Ability Measurement. In turn, 11 (31.4\%) studies evaluated QOL simultaneously with another psycho-physiological or psychosocial repercussion, with emphasis for "pain" (45.4\%) as repercussion most associated in the studies. The studies of said 
review $(11,14,20,21,22,38,39)$ evidenced that greater pain meant lower QOL of patients with leg ulcers and pressure lesion.

Thirty-three instruments were identified in the studies of this review, with $18(54.5 \%)$ being referents to assess QOL. Among them, we highlight the Short Form 36 Health Survey (SF-36), identified in eight (44.4\%) studies, and the Charing Cross Venous UIcer Questionnaire (CCVUQe), used in six (33.3\%). It should be emphasized that of the studies evaluating QOL, five (14.2\%) use more than one instrument to evaluate that same repercussion. Of these, one $(20.0 \%)$ study used four different instruments, and, in the rest $(80.0 \%)$ investigated, two instruments were identified.

Regarding the dimensions evaluated in the QOL instruments $(n=18)$, higher occurrence was observed of the referents to activities of daily life, identified in $13(72.2 \%)$ instruments. Questions corresponding to the evaluation of the dimension of "pain and discomfort" were found in nine $(50 \%)$ instruments, as well as "social aspects" in eight (44.4\%) and "emotional aspects" in six (33.3\%). It should also be noted that the same instrument contains an evaluation of more than one of the dimensions mentioned.

Some instruments, like the Venous Leg Ulcer QOL (VLU-QOL) guide the research considering the clinical characteristics according to the etiology of the ulcers, through most commonly observed symptoms.

In relation to the other repercussions, four instruments identified were used, each, in four (12.1 \%) studies: Diabetic Foot Ulcer Scale (DFS), Visual Analog Scale (VAS), Rosenberg Selfesteem Scale, and Hospital Anxiety and Depression Scale (HADS). The instruments Health Survey (SF-12) and Beck's depression and anxiety inventory were identified in three $(9.1 \%)$ studies each. Lastly, the Dermatology Quality Index (DLQI), EQ-5D Powerlessness Assessment Tool (PAT) questionnaire, and Loneliness scale (UCLA) were each used in two (6.1\%) studies.

Table 2. Human impacts and respective instruments of extended assessment applied among people with chronic wounds. Goiania, 2017

\begin{tabular}{|c|c|c|c|c|}
\hline $\begin{array}{l}\text { Impact } \\
\text { assessed }\end{array}$ & $\begin{array}{l}\text { Name of the } \\
\text { instrument }\end{array}$ & $\begin{array}{c}\text { Frequency } \\
(\mathrm{n}, \%) / \text { Studies }\end{array}$ & $\begin{array}{l}\text { Population } \\
\text { for which the } \\
\text { instrument was } \\
\text { elaborated }\end{array}$ & Description of the instrument \\
\hline \multirow{5}{*}{ QOL } & $\begin{array}{l}\text { 36-Item Short-Form } \\
\text { Health Survey* } \\
\text { (SF-36) }\end{array}$ & $\begin{array}{c}819.5 \% \\
\text { E9, E13, El6, E19, } \\
\text { E26, E30. E35, E36 }\end{array}$ & $\begin{array}{l}\text { Adults in diverse } \\
\text { clinical situations }\end{array}$ & $\begin{array}{l}\text { SF-36 is comprised of } 36 \text { items encompassed in eight components: Functional } \\
\text { capacity (10 items), physical aspects (four items), pain (two items), general } \\
\text { state of health (five items), vitality (four items), social aspects (two items), } \\
\text { emotional aspects (three items), mental health (five items), and one compara- } \\
\text { tive question on the current perception of health and one year ago. }\end{array}$ \\
\hline & $\begin{array}{l}\text { The Charing Cross } \\
\text { Venous Ulcer Ques- } \\
\text { tionnaire (CCVUQ) }\end{array}$ & $\begin{array}{l}614.6 \% \\
E 5, E 11, E 15, E 22 \\
E 24, E 27\end{array}$ & $\begin{array}{c}\text { People with venous } \\
\text { ulcer }\end{array}$ & $\begin{array}{l}\text { CCVUQ is composed of } 21 \text { items that identify four important domains of health: } \\
\text { Social interaction, domestic activities, aesthetics, and emotional state, yielding } \\
\text { scores of } 0 \text { - } 100 \text { in which a higher score indicates worse QOL. }\end{array}$ \\
\hline & $\begin{array}{l}\text { Diabetic Foot Ulcer } \\
\text { Scale-Short Form } \\
\quad \text { (DFS-SF)* }\end{array}$ & $\begin{array}{c}49.7 \% \\
\text { E7, El0. El4, E33 }\end{array}$ & $\begin{array}{l}\text { Patients with foot } \\
\text { ulcer due to compli- } \\
\text { cations of DM }\end{array}$ & $\begin{array}{l}\text { DFS-SF consists in } 58 \text { items (each in a 5-point Likert-type scale) grouped into } \\
11 \text { domains: Leisure, physical health, daily activities, emotions, noncompliance, } \\
\text { family, friends, treatment, satisfaction, positive attitudes, financial. }\end{array}$ \\
\hline & $\begin{array}{l}\text { 12-Item Short- } \\
\text { Form Health Survey } \\
\quad \text { (SF-12) }\end{array}$ & $\begin{array}{c}37.3 \% \\
E 6, E 25, \text { E3l }\end{array}$ & $\begin{array}{l}\text { Adults in diverse } \\
\text { clinical situations }\end{array}$ & $\begin{array}{l}\text { SF-12 is a reduced version of the SF-36, composed of } 12 \text { items that evaluate two } \\
\text { big components: The physical component or physical component score (PCS) and } \\
\text { the mental component or mental component score (MCS). The scores vary from } \\
0 \text { to } 100 \text { in which } 0 \text { represents worse QOL and } 100 \text { better QOL. }\end{array}$ \\
\hline & $\begin{array}{l}\text { Dermatology Life } \\
\text { Quality Index } \\
\text { (DLQI)* }\end{array}$ & $\begin{array}{l}24.8 \% \\
\text { E4, El8 }\end{array}$ & $\begin{array}{l}\text { Patients with } \\
\text { dermatological } \\
\text { problems }\end{array}$ & $\begin{array}{l}\text { DLQI has } 10 \text { items divided into four domains: Personal relationships, daily } \\
\text { activities, leisure, and treatment. The maximum score is } 30 \text {, with } 0 \text { indicating the } \\
\text { lower damage and } 30 \text { the greater commitment in the patient's QOL. }\end{array}$ \\
\hline
\end{tabular}




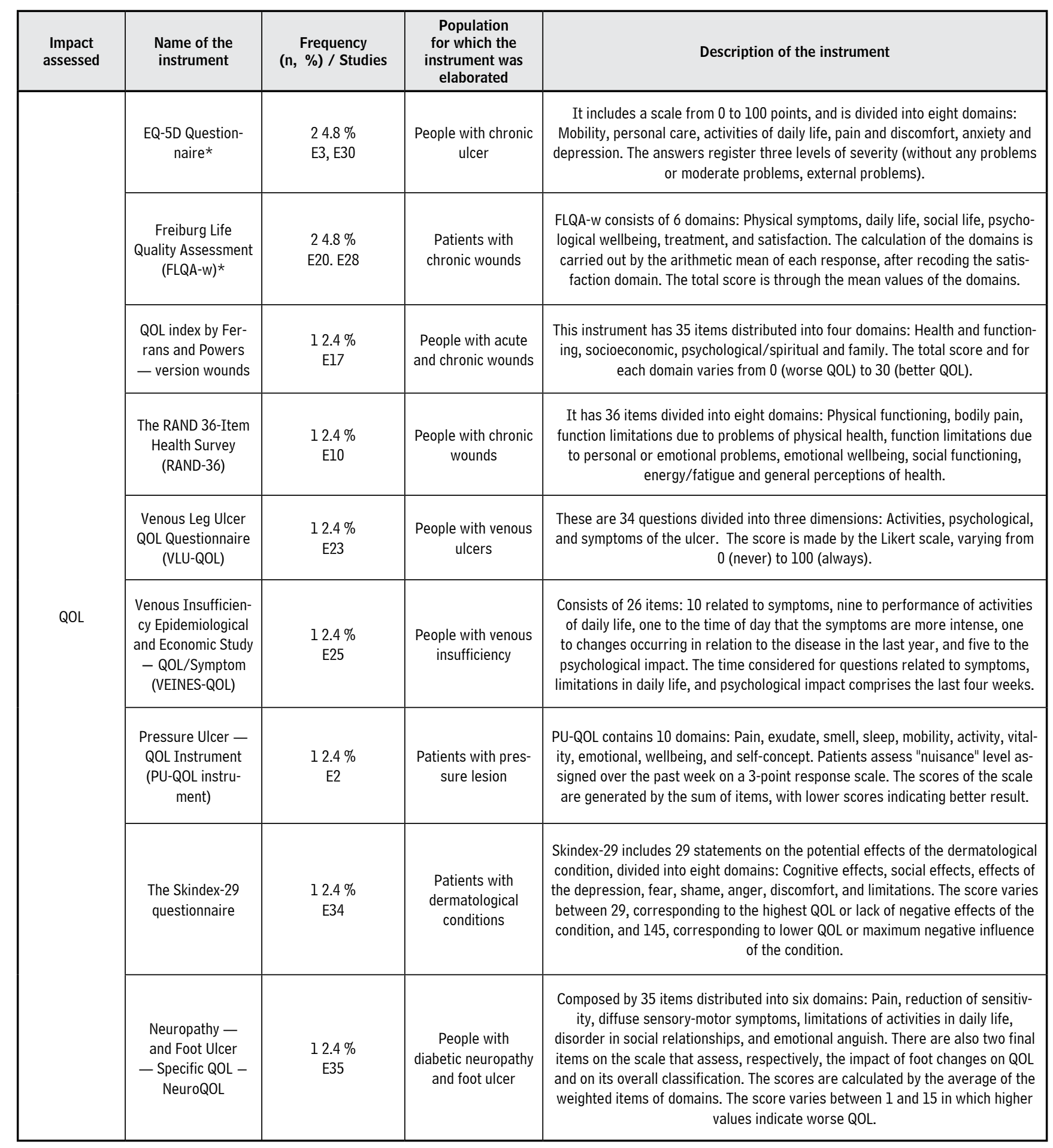




\begin{tabular}{|c|c|c|c|c|}
\hline $\begin{array}{l}\text { Impact } \\
\text { assessed }\end{array}$ & $\begin{array}{l}\text { Name of the } \\
\text { instrument }\end{array}$ & $\begin{array}{l}\text { Frequency } \\
(\mathrm{n}, \%) / \text { Studies }\end{array}$ & $\begin{array}{l}\text { Population } \\
\text { for which the } \\
\text { instrument was } \\
\text { elaborated }\end{array}$ & Description of the instrument \\
\hline \multirow{4}{*}{ QOL } & $\begin{array}{l}\text { Nottingham Health } \\
\text { Profile (NHP)* }\end{array}$ & $\begin{array}{l}12.4 \% \\
\mathrm{E} 12\end{array}$ & $\begin{array}{l}\text { Adults in diverse } \\
\text { clinical situations }\end{array}$ & $\begin{array}{c}\text { Divided into six domains: Level of energy, pain, emotional, sleep, social and } \\
\text { physical abilities. The score varies between } 0 \text { and 100, higher values represent } \\
\text { more negative interference QOL. }\end{array}$ \\
\hline & Wound QOL* & $\begin{array}{l}12.4 \% \\
\text { E20 }\end{array}$ & $\begin{array}{l}\text { People with chronic } \\
\text { wounds }\end{array}$ & $\begin{array}{l}\text { Composed of } 17 \text { items, with three domains: Daily life, bodily, and psychologi- } \\
\text { cal. Patients are asked how many times they felt any of the } 17 \text { items and they } \\
\text { respond (not even a little, a little, moderately, very much, extremely). }\end{array}$ \\
\hline & $\begin{array}{l}\text { The Cardiff Wound } \\
\text { Impact Schedule } \\
\text { (CWIS)* }\end{array}$ & $\begin{array}{l}12.4 \% \\
\text { E20 }\end{array}$ & $\begin{array}{l}\text { People with chronic } \\
\text { wounds }\end{array}$ & $\begin{array}{l}\text { CWIS consists of three domains: Wellbeing, physical symptoms, social life, and } \\
\text { daily life. Scores vary from } 0 \text { to 100, in which higher values indicate better QOL. }\end{array}$ \\
\hline & $\begin{array}{l}\text { Würzburg Wound } \\
\text { Score (WWS)* }\end{array}$ & $\begin{array}{l}12.4 \% \\
\text { E20 }\end{array}$ & $\begin{array}{l}\text { People with chronic } \\
\text { wounds }\end{array}$ & $\begin{array}{l}\text { WWS is composed of } 17 \text { items related to pain, sleep, happiness, frustration, } \\
\text { worry, smell, discomfort, fear, activities of daily life, mobility, limitation, depen- } \\
\text { dence, and financial. }\end{array}$ \\
\hline \multirow[b]{2}{*}{ Pain } & $\begin{array}{l}\text { Visual Analog Scale } \\
\qquad(\text { VAS)* }\end{array}$ & $\begin{array}{l}49.7 \% \text { El2, El4, } \\
\text { E30. E33 }\end{array}$ & $\begin{array}{l}\text { Adults in diverse } \\
\text { clinical situations }\end{array}$ & $\begin{array}{l}\text { VAS provides a one-dimensional measurement of pain intensity. It has anchors } \\
\text { of } 0 \text { (without pain) to } 10 \text { (worse pain possible). }\end{array}$ \\
\hline & $\begin{array}{l}\text { McGill Pain Ques- } \\
\text { tionnaire (MPQ) }\end{array}$ & $\begin{array}{l}12.4 \% \\
\text { E6 }\end{array}$ & $\begin{array}{l}\text { Adults in diverse } \\
\text { clinical situations }\end{array}$ & $\begin{array}{l}\text { Seeks to provide qualitative measurements of pain that can be analyzed statisti- } \\
\text { cally. Evaluates the sensory, affective, temporal and miscellaneous qualities } \\
\text { of pain. In addition, it presents an evaluation of the spatial distribution and } \\
\text { intensity of pain ("without pain" to "excruciating"). }\end{array}$ \\
\hline \multirow[t]{2}{*}{ Self-esteem } & $\begin{array}{l}\text { Rosenberg Self- } \\
\text { Esteem Scale } \\
\quad \text { (RSES) }\end{array}$ & $\begin{array}{c}49.7 \% \\
E 4, E 9, E 18, E 21\end{array}$ & Adult patients & $\begin{array}{l}\text { RSES is a 10-item questionnaire answered in a 4-point scale. Scores vary from } \\
0 \text { to 30; scores from } 15 \text { to } 25 \text { are considered within the normal interval, while } \\
\text { scores below } 15 \text { suggest feelings of low self-esteem. }\end{array}$ \\
\hline & $\begin{array}{l}\text { The Body Invest- } \\
\text { ment scale* }\end{array}$ & $12.4 \%$ E21 & Adult patients & $\begin{array}{l}\text { Includes } 20 \text { items grouped into four domains: Bodily feelings, body touch, bodily } \\
\text { care, and bodily protection. The items are scored in a 5-point Likert scale, vary- } \\
\text { ing from totally disagree (1) to totally agree (5). }\end{array}$ \\
\hline $\begin{array}{l}\text { Anxiety and } \\
\text { depression }\end{array}$ & $\begin{array}{l}\text { Hospital Anxiety } \\
\text { and Depression } \\
\text { Scale (HADS)* }\end{array}$ & $\begin{array}{c}49.7 \% \\
\mathrm{E} 4, \mathrm{E} 18, \mathrm{E} 37, \mathrm{E} 41\end{array}$ & $\begin{array}{l}\text { Adults in diverse } \\
\text { clinical situations }\end{array}$ & $\begin{array}{l}\text { HADS has } 14 \text { items, projected to measure anxiety and depression, most likely } \\
\text { to cause psychological suffering in patients (seven items for each subscale). } \\
\text { Answers to the items are indicated in a 4-point Likert scale from } 0 \text { to 3, with a } \\
\text { high score indicating more symptoms. }\end{array}$ \\
\hline \multirow{3}{*}{ Depression } & $\begin{array}{l}\text { Beck's Depression } \\
\text { Assessment Inven- } \\
\text { tory* }\end{array}$ & $\begin{array}{l}37.3 \% \text { E32, E38, } \\
\text { E39 }\end{array}$ & $\begin{array}{c}\text { Destined for pa- } \\
\text { tients over } 13 \text { years } \\
\text { of age }\end{array}$ & $\begin{array}{l}\text { Consists of } 21 \text { categories and each category has } 4 \text { points. The highest score } \\
\text { is } 63 \text {; the higher the score, higher degree of intensity of depression. } 0 \text { to } 10 \\
\text { indicates no symptom of depression, } 11 \text { to } 17 \text { indicates few symptoms, } 18 \text { to } 29 \text {, } \\
\text { moderate, and } 30 \text { to } 63 \text { indicates high level of depressive symptoms. }\end{array}$ \\
\hline & $\begin{array}{l}\text { 15-item Geriatric } \\
\text { Depression Scale }\end{array}$ & $\begin{array}{l}12.4 \% \\
\text { E } 29\end{array}$ & $\begin{array}{l}\text { Destined for elderly } \\
\text { patients }\end{array}$ & $\begin{array}{l}\text { Consists of } 15 \text { questions made in interview form with 'yes or no' answers, which } \\
\text { evaluate if the elderly patient has or does not have depressive symptoms. }\end{array}$ \\
\hline & $\begin{array}{l}\text { Patient Health } \\
\text { Questionnaire-9 } \\
\text { (PHQ-9) }\end{array}$ & $12.4 \%$ E40 & $\begin{array}{l}\text { Adults in diverse } \\
\text { clinical situations }\end{array}$ & $\begin{array}{l}\text { Composed of nine questions that evaluate the presence of nine symptoms of } \\
\text { depression: Depressed mood, anhedonia, problems sleeping, tiredness, change } \\
\text { in appetite or weight, feeling of guilt or uselessness, lack of concentration, } \\
\text { feeling slow or restless, and suicidal thoughts. And presents a tenth question } \\
\text { that evaluates the impact of these symptoms in activities of daily life. Each item } \\
\text { is considered positive if it remains for more than half the days in the last two } \\
\text { weeks. }\end{array}$ \\
\hline
\end{tabular}




\begin{tabular}{|c|c|c|c|c|}
\hline $\begin{array}{l}\text { Impact } \\
\text { assessed }\end{array}$ & $\begin{array}{l}\text { Name of the } \\
\text { instrument }\end{array}$ & $\begin{array}{c}\text { Frequency } \\
(\mathrm{n}, \%) / \text { Studies }\end{array}$ & $\begin{array}{l}\text { Population } \\
\text { for which the } \\
\text { instrument was } \\
\text { elaborated }\end{array}$ & Description of the instrument \\
\hline $\begin{array}{l}\text { Feeling of } \\
\text { powerless- } \\
\text { ness }\end{array}$ & $\begin{array}{l}\text { Powerlessness } \\
\text { Assessment Tool } \\
\text { (PAT) }\end{array}$ & $\begin{array}{l}24.8 \% \\
E l, E 8 .\end{array}$ & $\begin{array}{l}\text { Adults in post- } \\
\text { operatory }\end{array}$ & $\begin{array}{l}\text { The instrument consists of a measure of } 12 \text { items distributed into three } \\
\text { domains: Capacity to perform behavior, perception of the capacity to make deci- } \\
\text { sions, and emotional response to the control of situations. The PAT evaluates } \\
\text { the feeling of powerlessness in a 5-point Likert-type scale, varying from "never" } \\
\text { (1) to "always" (5). The total PAT varies between } 12 \text { and } 60 \text {, with higher scores } \\
\text { corresponding to strong feeling of powerlessness. }\end{array}$ \\
\hline Loneliness & $\begin{array}{l}\text { UCLA Loneliness } \\
\text { scale (version 3)* }\end{array}$ & $\begin{array}{l}24.8 \% \\
\text { E4, El8 }\end{array}$ & Not shown by study & $\begin{array}{l}\text { UCLA (Version 3) is a questionnaire with } 20 \text { items that measures the personal } \\
\text { perception of loneliness and of social isolation. The stronger these feelings } \\
\text { were, the higher the UCLA score. }\end{array}$ \\
\hline $\begin{array}{c}\text { Perceived } \\
\text { social support }\end{array}$ & $\begin{array}{l}\text { Multidimensional } \\
\text { scale of perceived } \\
\text { social support* }\end{array}$ & $\begin{array}{c}12.4 \% \\
\text { E32 }\end{array}$ & $\begin{array}{l}\text { Adults in diverse } \\
\text { clinical situations }\end{array}$ & $\begin{array}{l}\text { Consists of } 12 \text { items, evaluates the perception of adequate support perceived by } \\
3 \text { domains: Family, friends, and significant others. Likert-type scale in which the } \\
\text { lowest score is } 12 \text { and the highest is } 28 \text {, with the higher scores indicating higher } \\
\text { level of social support. }\end{array}$ \\
\hline Healing & $\begin{array}{l}\text { Pressure ulcer } \\
\text { scale of healing } \\
\text { (PUSH) }\end{array}$ & $\begin{array}{c}12.4 \% \\
\text { El5 }\end{array}$ & $\begin{array}{l}\text { People with pres- } \\
\text { sure lesion }\end{array}$ & $\begin{array}{l}\text { Evaluates three aspects of healing: Size of the ulcer, amount of exudate and } \\
\text { type of tissue. Each has a sub-score that will be added and will form the total } \\
\text { score. The lower the score, the better the prognosis. }\end{array}$ \\
\hline Functionality & $\begin{array}{l}\text { Foot and Ankle } \\
\text { Ability Measure- } \\
\text { ment (FAAM) }\end{array}$ & $\begin{array}{c}12.4 \% \\
\text { E19 }\end{array}$ & $\begin{array}{l}\text { Adults in diverse } \\
\text { clinical situations }\end{array}$ & $\begin{array}{l}\text { Developed as a specific measure to verify the functionality of people with } \\
\text { muscular-skeletal disorders of the ankle-foot complex. It evaluates two aspects: } \\
\text { Activity of daily life (ADL) and sports appraisals. The ADL subscale includes } 21 \\
\text { activities, and the sports subscale includes eight activities. Patients are asked } \\
\text { to register the difficulty the face with various activities. There are three scores, } \\
\text { one for each subscale and a total score. The maximum score in the ADL and } \\
\text { sports subscale is } 84 \text { and 32, respectively. }\end{array}$ \\
\hline General health & $\begin{array}{l}\text { The Short Form } \\
\text { Global Health of } \\
\text { PROMIS }\end{array}$ & $\begin{array}{c}12.4 \% \\
\text { E27 }\end{array}$ & $\begin{array}{l}\text { Patients with } \\
\text { chronic disease }\end{array}$ & $\begin{array}{l}\text { Composed of } 10 \text { items that evaluate aspects of physical, mental, and social } \\
\text { health, plus an item to classify general health. This instrument is composed } \\
\text { of two specific scales, Global Physical Health and Global Mental Health, each } \\
\text { composed of four items. The Global Physical Health scale includes items of } \\
\text { physical health (03), physical function (06), intensity of pain (07), and fatigue } \\
\text { (08). And the scale of Global Mental Health is constituted by items of QOL (02), } \\
\text { mental health (04), satisfaction with social activities and relationships (05), and } \\
\text { emotional problems (Global 10). The answer categories are Likert-type scales of } \\
5 \text { points, except for the Global } 07 \text { item, which evaluated by a scale from } 0 \text { to } 10 \\
\text { in which } 0 \text { means lack of pain and } 10 \text { presence of worse pain imaginable. }\end{array}$ \\
\hline Cognition & $\begin{array}{l}\text { Mini Mental - men- } \\
\text { tal exam }\end{array}$ & $\begin{array}{c}12,4 \% \\
\text { E29 }\end{array}$ & $\begin{array}{l}\text { Adults in diverse } \\
\text { clinical situations }\end{array}$ & $\begin{array}{l}\text { Mini-mental State consists of a test to examine the mental state that assesses } \\
\text { orientation, memory, attention, and language. Higher scores indicate better } \\
\text { cognitive performance. The maximum score is } 30 \text { points. Due to the influence } \\
\text { of schooling on the total scores of the Mini-mental State, the evaluation of the } \\
\text { result occurs according to the schooling of the individuals. }\end{array}$ \\
\hline
\end{tabular}

Source: Own elaboration. 


\section{Discussion}

Regarding the design diversity of the studies included, it is associated with the research question of this review that sought to know the instruments introduced in the literature for extended assessment of people with wounds. As expected, studies related to psychometrics were identified, however, it is possible to observe the scarcity of clinical research in this assessment context, making it difficult to judge the applicability of the instruments.

The greater occurrence of research carried out in American countries, especially Brazil, reinforces the potential to conduct investigations on this theme. Nursing still needs further investment to carry out studies like these, given that it is one of the professional areas with greatest contact with the studied population, and which, sometimes, identifies nuances of the multidimensional repercussions among these individuals in the daily care. In addition, research is a recommended assessment demand in specific guidelines to approach this population (2).

In relation to the characteristics of the population found in the articles in this review, the results reinforce the findings from the literature for the etiologies identified (50). This fact points to the presence of specific profiles that may help in directing actions in the context studied.

It is possible to identify association between sociodemographic data and psychosocial repercussions, like the highest occurrence of low self-esteem, anxiety, and depression in women, which can be related to a higher number of stressful factors, such as pregnancy, menopause, and social oppression (51, 52). Another example is the occurrence of depression associated to age, demonstrated by changing roles and, consequently, by alterations resulting from interaction and social function, in addition to continuous use of many medications $(53,54)$.

The prevalence of studies that address people with leg ulcers can be associated to the profile of the individuals in what refers to socioeconomic aspects. Because of their lower morbidity in relation to individuals with pressure lesion, leg ulcer patients still perform functions in the groups and social institutions to which they belong; people with pressure lesion, due to the most frequent comorbidities, like cancer and neurological disorders (45, 46), are unable to perform these roles. In this sense, it may be inferred that instruments specific to the etiology of the lesions can guide the approach and identify more precisely the broader repercussions, without ignoring the need to validate this affirmation in different clinical and cultural contexts.

The diversity of instruments existing in the literature to assess the human repercussions mentioned points to understanding the complexity of the investigation, as well as for the possibility of these instruments meeting different objectives, considering variables, like clinical practice, teaching, and research, which needs validation by other studies.

Evaluation of QOL, as the most frequent outcome investigated in the instruments found, draws attention to the scope of the theme and points to the possibility of exhausting the subjective assessment (holistic) of these individuals. However, it should be emphasized that the approach, in some instruments of QOL, is superficial or even inconsiderate in relation to certain repercussions, such as "feeling of powerlessness", "anxiety", "depression", and "social aspects" $(22,41,47)$. Said finding indicates that QOL instruments can be tracers and not determinants in judging the presence or absence of these repercussions in this population.

Pain was also investigated frequently in the instruments, being an important aspect in the multidimensional evaluation of professionals in this type of care, despite being detailed or inadequately addressed. Assessment of pain, if carried out regularly, allows nurses to become aware of the level of pain manifested by patients not only when conducting certain procedures. Additionally, the frequency of evaluation will enable obtaining information related to the intensity of pain that people with venous ulcers must endure or experience in their daily lives. Thus, it may be stated that the evaluation and registry of intensity of pain permit patients greater possibility of control over their condition, with positive effect on their capacity to develop strategies to cope with the problem. Assessment of pain is also a means of measuring the efficacy and response to treatment, and influences the prognosis $(19,22,28,29,30,46,47)$. Pain represents an infectious process, neuropathy (22), or even psycho-emotional aspects involved $(22,28,29)$. Through several instruments validated to evaluate the intensity and characteristic of pain, it is recommended to use the same instrument to facilitate comparison of results and evolution of cases. Such instruments can be determinant in the selection or adjustments in doses of analgesics, as well as in prescribing the most adequate coverage for healing (55). 
This study highlights the visual analogue scale of pain and the questionnaire on pain by de McGill as instruments to evaluate and measure pain in patients with wounds. Although specific instruments exist to aid in this evaluation, they are still poorly used in clinical practice. In a study conducted in Brazil, in four hospitals that had the so-called "curative commissions", merely $5 \%$ of the nurses used some specific instrument to assess pain (56). This fact points to the need for a review of managerial aspects and to greater understanding by professionals regarding the importance of this evaluation.

The greater occurrence of the use of the SF-36 can be justified because it is an instrument that addresses a greater diversity of the dimensions identified as human repercussions, besides comparing the current perception of health in different temporal cut-offs (57), or in clinical situations and different care scenarios (58). While promoting a wide-ranging assessment of various dimensions, this type of instrument does not address major repercussions that affect the chronic wound, such as self-esteem, anxiety, depression, feelings of powerlessness, and loneliness.

A search made with people with chronic wounds identified that the perception of those with chronic lesion is marked by pain, preconception, dependence for daily activities, and consequential emotional alterations. Patients face the adversities resulting from the lesion in different ways, and health professionals, especially nurses, must respect the individuality and understand how those repercussions affect patients (1).

In Nursing, theoretical references can help direct the holistic approach to this population, besides supporting the systematization of actions. The theory by Wanda de Aguiar Horta, "Theory of Basic Human Needs", represents simple possibilities applicable in various contexts of clinical practice (59), and which can be jointly implemented in the evaluation of subjective repercussions of this population.
Thus, the importance is evident of directed evaluation by the nurse to implement and use certain instruments, considering the social and clinical context of the population with wounds to be cared for.

\section{Conclusion}

Diverse instruments were identified for extended assessment of people with wounds, with those investigating QOL being the most frequent. The other subjective repercussions found in the instruments analyzed were: Anxiety, depression, loneliness, self-esteem, feelings of powerlessness, and perceived social support, in addition to specific instruments to evaluate mental state and healing.

The repercussions are, mostly, contained in instruments to evaluate QOL, but superficially and/or not very explicit, like in the SF-36, an instrument identified most frequently in the studies of this review. Hence, it is therein inferred that QOL instruments can be considered trackers of alterations of the aforementioned repercussions, but they hinder more directed judgment.

The findings in this research reinforce the contributions of using instruments for extended assessment of people with chronic wounds, and suggest the possibility of differentiated implications, according to the etiology of the lesions, psychosocial and psychospiritual needs of the individual, as well as the context to which they are destined, that is, teaching, clinical practice, or research.

It is also worth highlighting the importance of further studies that can validate the use of evaluation instruments in the various scenarios to indicate their evidence in a directed and, consequently, safer manner.

Conflict of interest: None declared. 


\section{References}

1. Oliveira MO, Pereira Jr AC, Pinto JSF, Vieira NF, Wichr P. Significado da ferida para portadores de úlceras cônicas. Cogit Enferm. 2011; 16(3): 471-7. DOI: 10.5380/ce.v16i3.20178

2. Wounds UK. Best practice statement: holistic management of venous leg ulceration. London. 2016. Available in: https:// lohmann-rauscher.co.uk/downloads/VLU_BPS_Web.pdf

3. Coluci MCO, Alexandre MNC, Milani D. Construção de instrumentos de medida na área de saúde. Cien Saúde Colet. 2015; 20(3): 925-36. DOI: 10.1590/1413-81232015203.04332013

4. Barham L, Devlin N. Patient-reported outcome measures: implications for nursing. Nurs Stand. 2011; 25(18): 42-5. Available in: https://www.ncbi.nlm.nih.gov/pubmed/21309321

5. Cano SJ, Hobart JC. The problem with health measurement. Patient Prefer Adherence. 2011; 5: 279-90. DOI: 10.2147/ PPA.S14399

6. Galvão TF, Pansani TS. Principais itens para relatar revisões sistemáticas e meta-análises: a recomendação PRISMA. Epidemiol Serv Saude 2015; 24(2): 335-42. DOI: 10.2147/PPA.S14399

7. Mendes KDS, Silveira RCC, Galvão CM. Revisão integrativa: métodos para a incorporação de evidências na saúde e na enfermagem. Texto Contexto Enferm. 2008; 17(4): 758-64. Available in: http://www.scielo.br/pdf/tce/v17n4/18.pdf

8. Joanna Briggs Institute (JBI). Joanna Briggs Institute Reviewers' Manual [Internet]. Adelaide; 2014. Available in: http:// joannabriggs.org/assets/docs/sumari/ReviewersManual-2014.pdf

9. Almeida SA, Salomé GM, Dutra RAA, Ferreira LM. Feelings of powerlessness in individuals with either venous or diabetic foot ulcers. J Tissue Viability. 2014; 23(3): 109-14. DOI: 10.1016/j.jtv.2014.04.005

10. Gorecki C, Lamping DL, Nixon J, Brown JM, Cano S. Applying mixed methods to pretest the Pressure Ulcer Quality of Life (PU-QOL) instrument. Qual Life Res. 2012; 21(3): 441 - 51. DOI: 10.1007/s11136-011-9980-x

11. Renner R, Seikowski K, Simon JC. Association of pain level, health and wound status in patients with chronic leg ulcers. Acta Derm Venereol. 2014; 94(1): 50-3. DOI: 10.2340/00015555-1635

12. Kouris A, Christodoulou C, Efstathiou V, Tsatovidou R, Torlidi-Kordera E, Zouridaki E, et al. Comparative study of quality of life and psychosocial characteristics in patients with psoriasis and leg ulcers. Wound Repair Regen. 2016; 24(2): 443-6. DOI: 10.1111/wrr.12416

13. Gonzalez de la Torre H, Quintana-Lorenzo M, Perdomo-Pérez E, Verdú J. Correlation between health-related quality of life and venous leg ulcer's severity and characteristics: a cross-sectional study. Int Wound J. 2016; 14(2): 360-8. DOI: $10.1111 /$ iwj. 12610

14. Hopman WM, Van Den Kerkhof EG, Carley ME, Kuhnke JL, Harrison MB. Factors associated with health-related quality of life in chronic leg ulceration. Qual Life Res. 2014; 23(6): 1833-40. DOI: 10.1007/s11136-014-0626-7

15. Spanos K, Saleptsis V, Athanasoulas A, Karathanos C, Bargiota A, Chan P, et al. Factors associated with ulcer healing and quality of life in patients with diabetic foot ulcer. Angiology. 2017; 68(3): 242-50. DOI: 10.1177/0003319716651166

16. Salomé GM, Openheimer DG, Almeida SA, Bueno MLGB, Dutra RAA, Ferreira LM. Feelings of powerlessness in patients with venous leg ulcers. J Wound Care. 2013; 22(11): 628-34. Available in: https://www.woundsresearch.com/article/ feelings-powerlessness-patients-diabetic-foot-ulcers

17. Meneses LC, Blanes L, Veiga DF, Gomes HG, Ferreira LM. Health-related quality of life and sel-steem in patients with diabetic foot ulcers: results of a cross-sectional comparative study. Ostomy Wound Manage. 2011; 57(3): 36-43. Available in: https://www.ncbi.nlm.nih.gov/pubmed/21422482

18. Sekhar MS, Thomas RR, Unnikrishnan MK, Vijayanarayana V, Rodrigues GS. Impact of diabetic foot ulcer on healthrelated quality of life: a cross-sectional study. Semin Vasc Surg. 2015; 28( 3- 4): 165-71. DOI: 10.1053/j.semvascsurg.2015.12.001 
19. Araújo RO, Silva DC, Souto RQ, Pergola-Marconata AM, Costa IKF, Torres GV. Impacto de úlceras venosas na qualidade de vida de indivíduos atendidos na atenção primária. Aquichan. 2016; 16(1): 56-66. DOI: 10.5294/aqui.2016.16.1.7

20. Furtado K, Pina E, Moffatt CJ, Franks PJ. Leg ulceration in Portugal: quality of life. Int Wound J. 2008; 5(1): 34-9. DOI: $10.1111 / \mathrm{j} .1742-481 X .2007 .00342 . x$

21. Raspovic K, Kimberlee B. Midfoot Charcot neuroarthropathy in patients with diabetes: the impact of foot ulceration on self-reported quality of life. Foot Ankle Spec. 2015; 8(4): 256-9. DOI: 10.1177/1938640015585957

22. Vymetalová R, Zelenicová R. Painful ulceration and quality of life whith the diabetic foot syndrome. Cent Eur J Nurs Midw. 2016; 7(4): 512-7. DOI: 10.15452/CEJNM.2016.07.0023

23. González-Consuerga RV, Soriano JV. Calidad de vida y cicatrización en pacientes con úlceras de etiología venosa. Validación del Charing Cross Venous Ulcer Questionnaire, versión española (CCVUQ-e) y del Pressure Ulcer Scale for Healing, versión española (PUSH-e). Resultados preliminares. Gerokomos. 2011; 22(3): 131-6. Available in: http://periodicals.osu.eu/cejnm/5_131_painful-ulceration-and-quality-of-life-of-patients-with-the-diabetic-foot-syndrome.html

24. Dias TYAF, Costa IKF, Melo MDM, Torres SMSGSO, Maia EMC, Torres GV. Quality of life assessment of patients with and without venous ulcer. Rev Lat Am Enfermagem. 2014; 22(4): 576-81. DOI: 10.1590/0104-1169.3304.2454

25. Santos KFR, Silva PR, Ferreira VT, Domingues EAR, Ribeiro I, Simoes A, et al. Quality of life of people with chronic ulcers. J Vasc Nurs. 2016; 34(4): 131-6.DOI: 10.1016/j.jvn.2016.06.003

26. Kouris A, Armyra K, Christodoulou C, Sgontzou T, Karypidis D, Kontochristopoulos G, et al. Quality of life psychosocial characteristics in Greek patients with leg ulcers: a case control study. Int Wound J. 2014; 13(5): 744-7. DOI: 10.1111/ iwj.12363

27. Raspovic KM, Wukich DK. Self-reported quality of life and diabetic foot infections. J Foot Ankle Surg. 2014; 53(6): 1-4. DOI: $10.1053 / \mathrm{j} . j f a s .2014 .06 .011$

28. Blome C, Baade K, Debus ES, Price P, Augustin M. The "wound-QoL": a short questionnaire measuring quality of life in patients with chronic wounds based on three established disease-specific instruments. Wound Repair Regen. 2014; 22(4): 504-14. DOI: 10.1111/wrr.12193

29. Salomé GM, Almeida AS, Pereira MTJ, Massahud MR, Moreira CNO, Brito MJA, et al. The impact of venous leg ulcers on body image and self-esteem. Adv Skin Wound Care. 2016; 29(7): 316-21. DOI: 10.1097/01.ASW.0000484243.32091.0c

30. Couto RC, Leal FJ, Pitta JBB, Bezerra RCB, Segundo WSS, Porto TM. Tradução e adaptação cultural do Charing Cross Venous Ulcer Questionnaire - Brasil TT. J Vasc Bras. 2012; 11(2): 102-6. DOI: 10.1590/S1677-54492012000200006

31. Araújo RB, Fortes MRP, Abbade LPF, Miot HM. Translation, cultural adaptation to Brazil and validation of the Venous leg ulcer quality of life questionnaire (VLU-QoL-Br). Rev Assoc Med Bras. 2014; 60(3): 249-54. DOI: 10.1590/18069282.60.03.014

32. Couto RC, Leal FJ, Pitta GBB. Validação do questionário de qualidade de vida na úlcera venosa crônica em língua portuguesa (Charing Cross Venous Ulcer Questionnaire - CCVUQ - Brasil). J Vasc Bras. 2016; 15(1): 4-10. DOI: 10.1590/16775449.003015

33. Bland JM, Dumville JC, Ashby RL, Gabe R, Stubbs N, Adderley U, et al. Validation of the VEINES-QOL quality of life instrument in venous leg ulcers: repeatability and validity study embedded in a randomised clinical trial. BMC CardiovasC Disord. 2015; 15: 85. DOI 10.1186/s12872-015-0080-7

34. Lima Neto PM, Lima PHS, Santos FDRP, Jesus LMS, Lima RJCP, Santos LH. Qualidade de vida de pessoas com pé diabético. Rev RENE. 2016; 17(2): 191-7. DOI: 10.15253/2175-6783.2016000200006

35. Tafernaberry G, Otero G, Agorio C, Dapueto JJ. Evaluation of the Charing Cross Venous Ulcer Questionnaire in patients with chronic venous ulcers in Uruguay. Rev Med Chile. 2016; 144: 55-65. DOI: 10.4067/S0034-98872016000100008

36. Augustim M, Herberger K, Rustenbach SJ, Schäfer I, Zschocke I, Blome C. Quality of life evaluation in wounds: validation of the Freiburg Life Quality Assessment-wound module, a disease-specific instrument. Int Wound J. 2010; 7(6): 493-501.DOI: $10.1111 /$ j.1742-481X.2010.00732.x 
37. Galhardo VAC, Magalhães MG, Blanes L, Juliano Y, Ferreira LM. Healt-related quality of life and depression in older patients with pressure ulcers. Wounds. 2010; 22(1): 20-6. Available in: https://www.ncbi.nlm.nih.gov/pubmed/25901458

38. Essesx HN, Clark M, Sims J, Warriner A, Cullun N. Health-related quality of life in hospital inpatients with pressure ulceration: assessment using generic health-related quality of life measures. Wound Repair Regen. 2009; 17(6): 797-805. DOI: $10.1111 /$ j.1524-475X.2009.00544.x

39. Guarnera G, Tinelli G, Abeni D, Di pietro C, Sampogna F, Tabolli S. Pain and quality of life in patients with vascular leg ulcers: na italian multicentre study. J Wound Care. 2007; 16(8): 347-51. DOI: 10.12968/jowc.2007.16.8.27856

40. Yildiz E, Asti T. Determine the relationship between perceived social support and depression level of patients with diabetic foot. J Diabetes Metab Disord. 2015; 14: 59. DOI: 10.1186/s40200-015-0168-8

41. Macioch T, Sobol E, Krakowieck A, Mrozikiewicz-Rakowska B, Kasprowicz M, Hermanowski T. Health related quality of life in patients with diabetic foot úlceration - translation and Polish adaptation of Diabetic Foot Ulcer Scale short form. Health Qual Life Outcomes. 2017; 15(1): 15.DOI: 10.1186/s12955-017-0587-y

42. Szewczyk MT, Mościcka P, Jawień A, Cwajda-Białasik J, Cierzniakowska K, Ślusarz R, et al. Quality of life in patients with leg ulcers or skin lesions: a pilot study. Postepy Dermatol Alergol. 2015; 32(6): 465-9. DOI: 10.5114/pdia.2014.40983

43. Xavier ATF, Foss MC, Marques Jr W, Santos CB, Onofre PTBN, Pace AE. Cultural adaptation and validation of the Neuropathy - and Foot Ulcer - Specific Quality of Life instrument (NeuroQol) for Brazilian Portuguese - Phase 1. Rev Lat Am Enfermagem. 2011; 19(6): 1352-61. DOI: 10.1590/S0104-11692011000600011

44. Almeida SA, Silveira MM, Espirito Santo PF, Pereira RC, Salomé GM. Avaliação da qualidade de vida em pacientes com diabetes mellitus e pé ulcerado. Rev Bras Cir Plast. 2013; 28(1): 142-6. DOI: 10.1590/S1983-51752013000100024

45. Chapman Z, Shuttleworth CMJ, Huber JW. High levels of anxiety and depression in diabetic patients with Charcot foot. J Foot Ankle Res. 2014; 7(1): 22.DOI: 10.1186/1757-1146-7-22

46. Espirito Santo PF, Almeida SA, Pereira MTJ, Salomé GM. Avaliação do nível de depressão em individuos com feridas crônicas. Rev Bras Cir Plast. 2013; 28(1): 665-71. Available in: http://www.rbcp.org.br/details/1468/avaliacao-do-nivel-de-depressao-em-individuos-com-feridas-cronicas

47. Salomé GM, Blanes L, Ferreira LM. Assessment of depressive symptoms in people with diabetes mellitus and foot ulcers. Rev Col Bras Cir. 2011; 38(5): 327-33. DOI: 10.1590/s0100-69912011000500008

48. Willians LH, Rutther CM, Katon WJ, Reiber GE, Ciechanowski P, Heckbert SR, et al. Depression and incident diabetic foot ulcers: a prospective cohort study. Am J Med. 2010; 123(8): 748-75. DOI: 10.1016/j.amjmed.2010.01.023

49. Iversen MM, Midthjell K, Tell GS, Moum T, Ostbye T, Nortvedt MW, et al. The association between history of diabetic foot ulcer, perceived health and psychological distress: the Nord-Trøndelag Health Study. BMC Endocr Disord. 2009; 9:18.DOI: 10.1186/1472-6823-9-18

50. de Oliveira BGRB, Castro JBA, Granjeiro JM. Panorama epidemiológico e clínico de pacientes com feridas crônicas tratados em ambulatório. Rev Enferm UERJ. 2013; 21(15): 612-7. Available in: https://www.e-publicacoes.uerj.br/index. php/enfermagemuerj/article/view/10035

51. Pompeo DA, Eid LP, Carvalho IG, Bertoli ES, de Oliveira NS. Autoestima de pacientes com doença arterial coronariana. Rev Rene. 2017; 18(6): 712-19. DOI: 10.15253/2175-6783.2017000600002

52. Gomes TEB, Ivo OP. Sistematização da assistência de enfermagem em mulheres com sintomatologia depressiva: uma revisão sistemática. Id on Line Rev M Psic. 2017; 11 (38): 835-48. Available in: https://idonline.emnuvens.com.br/id/ article/view/957

53. Soares SM, Silva AB, Santos JFG, Silva LB. Associação entre depressão e qualidade de vida em idosos: atenção primária à saúde. Rev Enferm UERJ. 2017; 25: e19987. Available in: https://www.e-publicacoes.uerj.br/index.php/enfermagemuerj/article/view/19987

54. Prata HL, Alves Jr ED, Paula FL, Ferreira SM. Envelhecimento, depressão e quedas: um estudo com os participantes o Projeto Prev-Quedas. Fisioter Mov. 2011; 24(3): 437-43. Available in: http://www.scielo.br/pdf/fm/v24n3/08.pdf 
55. Ministerio de Sanidad, Servicios Sociales e Igualdad. Guía para la prevención y manejo de las UPP y heridas crónicas. Espanha. 2015. Available in: http://www.ingesa.mscbs.gob.es/estadEstudios/documPublica/internet/pdf/Guia_Prevencion_UPP.pdf

56. Oliveira RA, Gualter WJS, Shaff P, Silva VCF, Cesaretti IUR. Análise das intervenções de enfermagem adotadas para alívio e controle da dor em pacientes com feridas crônicas: estudo preliminar. ESTIMA — Braz J Enterestomal Ther. 2005; 3(2). Available in: https://www.revistaestima.com.br/index.php/estima/article/view/12

57. Ware JE, Sherbourne CD. The MOS 36-item short-form health survey (SF-36): Conceptual framework and item selection. Med Care. 1992; 30(6): 473-83. Available in: https://www.ncbi.nlm.nih.gov/pubmed/1593914

58. Souza DMST, Veiga DF, Santos ID, Abla LE, Juliano Y, Ferreira LM. Health-related quality of life in elderly patients with pressure ulcers in different care settings. J Wound Ostomy Continence Nurs. 2015; 42: 325-59. DOI: 10.1097/ WON.0000000000000142

59. Anízio BKF. Construção de instrumento de coleta de dados para pessoas com feridas embasados na teoria de Horta [Dissertação de Mestrado em Cuidado em Enfermagem e Saúde]. João Pessoa: Universidade Federal da Paraíba; 2015. Available in: https://repositorio.ufpb.br/jspui/handle/tede/7590 